\title{
An analytical history of terrorism, 1945-2000
}

\author{
WILLIAM F. SHUGHART II \\ Department of Economics, The University of Mississippi, P. O. Box 1848, University, MS 38677- \\ 1848 USA; shughart@olemiss.edu
}

\begin{abstract}
This paper traces the history of modern terrorism from the end of the Second World War to the beginning of the twenty-first century. It divides that history into three stylized waves: terrorism in the service of national liberation and ethnic separatism, left-wing terrorism, and Islamist terrorism. Adopting a constitutional political economy perspective, the paper argues that terrorism is rooted in the artificial nation-states created during the interwar period and suggests solutions grounded in liberal federalist constitutions and, perhaps, new political maps for the Middle East, Central Asia and other contemporary terrorist homelands.
\end{abstract}

Keywords: Terrorism; national liberation; ethnic separatism; left-wing terrorism; Islamist terrorism; rational choice; constitutional political economy.

That could very well have happened, because what did not happen back then? — Fyodor Dostoevsky ([1872] 1994, p. 3)

\section{Introduction}

On the morning of 8 May 1945 most of the world was celebrating V.E. Day. The boulevards of Paris, London and New York were filled to overflowing with jubilant crowds awakening to news that the Nazis had capitulated at long last. So, too, were the streets of the Algerian market town of Sétif, where the colons were gathering to join in spirit their compatriots in metropolitan France rejoicing in the ending of the mother country's five-year-long nightmare of surrender to Hitler's armies, occupation, collaboration and massive destruction at the hands of the liberating Allied forces (Horne 1977, p. 23).

Marching toward Sétif's monument aux morts, where they intended to lay a commemorative wreath, the colons were confronted by a Muslim mob pouring in from the outskirts of town with something altogether different in mind. Some 8000 strong, carrying the green-and-white flag symbolizing resistance to French colonialism and unfurling banners bearing provocative slogans such as "For the Liberation of the People, Long Live Free and Independent 
Algeria!", the Muslims had seized the day marking European release from the Third Reich's grip to demonstrate in favor of Algerian independence (ibid., p. 25).

With only twenty small-town gendarmes available to maintain order, the inevitable soon happened: someone tore a banner from the hands of a Muslim demonstrator, a shot rang out, and blood already hot on both sides boiled over. It took five days for peace to be restored. By the time French troops had been mobilized and rushed to Sétif, scores of women had been brutally raped, 103 Europeans had been murdered, many of their corpses mutilated horrifically, and perhaps another hundred had been wounded. By a later official count, between 1020 and 1300 Muslims died in the vigilantism and indiscriminant reprisal the massacre provoked; Cairo radio immediately claimed that 45,000 native Algerians had been killed (ibid., pp. 25-27). Thus, even before the Enola Gay had sortied under Harry Truman's orders to inaugurate the nuclear age at Hiroshima, the postwar era of terrorism had begun.

This paper summarizes the history of terrorism from the bloodbath at Sétif to December 2000. The discussion is organized around three overlapping waves of terrorism that successively have taken center stage in world affairs since the end of the Second World War. The first of these waves, which started at Sétif and ended with the withdrawal of American troops from the jungles of Southeast Asia, saw terrorism placed in the service of ethnic separatism and national liberation. Unleashed by the shrinking of the French and British empires, and emboldened by the self-determination language of the Atlantic Charter, colonial peoples in Algeria, Cochin China (Vietnam), Palestine and Cyprus sought, often by violent means, to rid themselves of foreign rule and to create their own independent nation-states. The second wave began on 22 July 1968 , when Palestinian terrorists, to avenge Egypt's defeat in the 1967 Six Day War, hijacked an El Al flight from Rome to Tel Aviv. Terrorism was elevated to the international stage over the next 
two decades as ethno-national movements in the Netherlands, Turkey and elsewhere attempted to duplicate the Palestine Liberation Organization's success in galvanizing popular opinion. Fueled by opposition to the Vietnam War, conscription and anti-Americanism in general, leftwing terrorist groups in Europe and North American, such as the Red Brigades, the Red Army Faction and the Weathermen, occasionally aided and abetted by the PLO, waged campaigns of political assassinations, bombings and hijackings that continued until the fall of the Berlin Wall, at which time the third wave of postwar terrorism already was underway. This last wave, mostly Muslim in origin, was set in motion by the Iranian Revolution in 1979, and is still ongoing, pushed forward in Central Asia by the collapse of the Soviet Union, in the Middle East by animus to American support of Israel, and inspired everywhere - from Algeria to Chechnya, Kashmir, Indonesia, the Philippines and beyond - by pan-Islamic dreams of uniting fundamentalist Muslim states, freed from western cultural contamination, under Caliphate hegemony and Shar'ia law.

The overarching analytical framework for the discussion is one of cartographic and constitutional failure. Terrorism is seen as a predictable response to the artificial nation-states created at the Paris Peace Conference, when the colonial powers, presiding at the autopsy of the Ottoman Empire, reconfigured much of Europe and the Middle East without regard for traditional ethnic homelands or customary patterns of trade (Fromkin 1989; Macmillan 2002; Shughart 2004). Some close-knit groups were divided by new, unwanted national borders; others were marginalized politically under governments controlled by irreconcilably different ethnic or religious factions. In the interwar period, internal conflicts, never far from the surface, were for the most part held in check by autocrats supported at arm's length by the imperial powers, by colonial administrators who ruled indirectly through puppet regimes, or by repressive Soviet 
hegemony. Once the first two of these stabilizing forces weakened at the Second World War's end, ethnic nationalists actively began to seek the self-determination they had first been promised by Woodrow Wilson. Because these groups could not successfully wage conventional war against the larger, better equipped standing armies fielded either by distant colonial rulers or by local autocrats bent on maintaining control of the levers of political power, terrorism became the strategy of choice.

\section{Terrorism defined}

Each of the active groups, while proselytizing and spreading its side-branches to infinity, has as its task, by a systematic and denunciatory propaganda, ceaselessly to undermine the importance of the local powers, to produce bewilderment in communities, to engender cynicism and scandal, complete disbelief in anything whatsoever, a yearning for the better, and, finally, acting by means of fires as the popular means par excellence, to plunge the country, at the prescribed moment, if need be, even into despair.

— Fyodor Dostoevsky ([1872] 1994, p. 547)

They strike at the outskirts of the camp. Then when we sound the call to arms, they vanish. This is the most demoralizing kind of warfare.

— Gore Vidal ([1964] 1986, p. 428)

Terrorism is theater.

— Brian Jenkins ${ }^{1}$

It is conventional to start any discussion of terrorism by attempting to define it (e.g., Hoffman 1998, pp. 13-44; Pillar 2001, pp. 12-18). Is terrorism the same thing as guerrilla warfare? Does it include kidnappings and assassinations of political leaders? Can the term be applied to a state's methodical repression of its own citizens, as in the cold-blooded purges of the Stalinist era, in the depredations of Papa Doc's Tonton Macoutes, or in the horror of Pol Pot's killing fields? Must it be transnational, originating in one country but targeting another, or can terrorists be homegrown, as were Timothy McVeigh and his accomplices? What, if anything, distinguishes a 
terrorist from a "revolutionary", an "insurgent", a "freedom fighter", a "martyr" or an ordinary criminal?

\subsection{Orthodox definitions of terrorism}

Title 22 of the United States Code, $\S 2656 \mathrm{f}(\mathrm{d})$, defines terrorism as

premeditated, politically motivated violence perpetrated against noncombatant targets by subnational groups or clandestine agents, usually intended to influence an audience. (Office of the Coordinator for Counterterrorism 1997, p. vi)

That is the definition adopted by the US Department of State. The Federal Bureau of Investigation and the Department of Defense both give slightly different meanings to the term, highlighting the terrorist's "unlawful use of force or violence" (emphasis added), explicitly including both people and property as potential targets, and crediting terrorism with furthering social, religious, or ideological goals, in addition to political ones - objectives which are pursued through coercion or intimidation (Hoffman 1998, p. 38).

As the literature on terrorism has evolved, the definition of the term progressively has been embellished. Contemporary scholarship attributes at least four distinctive characteristics to it. First and foremost, terrorism is violence (or its threat) for political effect (ibid., p. 15; Sandler 2005b). Second, terrorism is "a planned, calculated, and indeed systematic act" (Hoffman 1998, p. 15). Third, terrorists are not bound by established rules of warfare or codes of conduct (ibid., p. 35), and, fourth, terrorism is "designed to have far-reaching psychological repercussions beyond the immediate victim or target" (ibid., p. 43). ${ }^{2}$

While these embellishments have identified and clarified important aspects of the terrorist enterprise, the concept remains unavoidably subjective, especially so in the case of anticolonial terror. Resorting to legalisms is not particularly helpful. Defining terrorism as the "unlawful use of violence", for example, forces one to classify as terrorists the Americans who 
rebelled against the lawfully constituted government of King George III. One man's terrorist will always be another man's freedom fighter. Conor Cruise O'Brien, for example, refuses to attach the terrorist label to anyone resisting an authoritarian regime (Crenshaw 1990, p. 13). According to Yassir Arafat, "the difference between the revolutionary and the terrorist lies in the reason for which each fights. For whoever stands by a just cause and fights for the freedom and liberation of his land from the invaders, the settlers and the colonialists, cannot possibly be called a terrorist..." (quoted in Hoffman 1998, p. 26).

Although it does not steer clear of all of the normative stumbling blocks, the US State Department comes closest to supplying a comprehensive definition of terrorism, provided that it is expanded to include not only actual violence directed at noncombatant targets, but also its threat. Terrorists, in short, seek to achieve their goals, whatever they may be, ${ }^{3}$ by disrupting daily life and creating a sense of insecurity amongst ordinary people, intentionally generating “massive fear" (Cooper 2001, p. 883). Uncertainty is therefore a key element in the terrorist group's brutal calculus: “A man can face known danger. But the unknown frightens him” (Heinlein [1966] 1994, p. 75). Or, to put it in terms more familiar to economists, "there are few incentives more powerful than the fear of random violence - which, in essence, is why terrorism is so effective" (Levitt and Dubner 2005, p. 62).

Creating a climate of fear requires fostering the belief that everyone is a potential target “collateral damage is not in [terrorism's] lexicon", as the 9/11 Commission observed (National Commission on Terrorist Attacks upon the United States 2004, p. xvi; emphasis in original) and, as one of this section's epigraphs suggests, realizing that objective in turn requires terrorists to ply their bloody trade in ways that attract extensive media coverage. Publicity is essential to terrorism because terrorist groups do not in general aim to effect policy change directly or 
necessarily even to elicit sympathy for their causes. Indeed, terrorist violence can, by producing indiscriminant death and destruction, turn public opinion against the responsible group (Crenshaw 1990, p. 17), compromising its ability to operate clandestinely and to raise needed funds, both of which reduce its chances of success. Terrorists instead choreograph their attacks mainly to intimidate, to panic an alarmed citizenry into demanding that national leaders somehow put right the perceived wrongs that serve, at least to the terrorists themselves, as justifications for their murderous campaigns (ibid., p. 18).

\subsection{Terrorists as rational actors}

No matter how terrorism is defined, however, it is increasingly clear that many of its facets can be understood by modeling terrorists as rational actors. Until very recently, the scholarly literature on terrorism was dominated by psychologists and sociologists, who looked for psychosocial reasons underlying behavior that, at least on the surface, seems absurdly irrational. The outward aberrations of terrorism include not only the terrorist's willingness to take innocent lives but, most spectacularly in the case of suicide bombers, his readiness to die for a cause. ${ }^{4}$

Scholars adopting the psycho-social point of view sought to locate terrorism's origins in character traits predisposing individuals to rebelliousness and violence, in conditions of poverty and political powerlessness leading to disaffection and disengagement from society at large, and in the social dynamics of terrorist groups themselves (e.g., Post 1990). ${ }^{5}$ Attempts to develop a composite personality profile of the typical terrorist have by and large been unsuccessful, however. Although "most terrorists have been young, some very young", and "the vast majority have been male" (Laqueur 1999, p. 80), no common threads of race, ethnicity, education, income, employment or social status run through the individuals and groups who have engaged in terrorist activities, either now or in the past. Nor, apparently, does terrorism have systematic 
causes rooted in "genetic factors, psychological difficulties in early childhood, a disturbed family life, or identification with the underclass" (ibid., p. 79). As a unique personality type, the representative terrorist does not exist; "there never was such a person" (ibid.).

The rational choice perspective (e.g., Landes 1978; Sandler, Tschirhart and Cauley 1983; Crenshaw 1990; Enders and Sandler 1993, 1995; Frey 2004), by contrast, treats terrorists and terrorist groups as deliberate actors whose behavior can be modeled within the same framework developed by economists to study human action in more ordinary settings. Within that framework, terrorists, like Homo economicus, are assumed to be motivated primarily, but not solely, by self-interest. They maximize utility, broadly defined, not simply income or wealth. As such, decisions to join a terrorist group and to participate in terrorist action hinge on the individual's evaluation of the probable benefits and costs to him personally, both suitably discounted. The potential gains from participation include the expected payoffs to members (wealth, power, fame and patronage) if the group is successful; the potential costs of becoming a terrorist include the possibilities of arrest, imprisonment, injury and death. Participation decisions also turn on the individual's evaluation of the relative benefits and costs of joining the opposition, a choice which may provide salient rewards if terrorism is suppressed, but which also increases his visibility as a terrorist target, as well as those of remaining inactive. The rationalchoice calculus informing the last option takes into account such factors as the costs the individual will incur if his failure to act increases the likelihood that the terrorist group will succeed and his expectation of being a counted among the statistics of collateral damage. ${ }^{6}$

The fruits of terrorism are something of a public good. Because the benefits of a successful terrorist campaign will be shared by everyone belonging to the group as well as by outsiders who are sympathetic to its cause, selective incentives, including pecuniary rewards; 
access to education, job training and social services otherwise unavailable to group members or their families (Zakaria 2003, p. 142); promises of compensation to relatives in the event of disablement or death; and even the assurance of a martyr's paradise often will be necessary to elicit optimal individual effort and to overcome the free-riding that inevitably plagues collective action (Olson 1965; Tullock 1974; Rathbone and Rowley 2003, p. 559).

Rational choice modeling yields insights into terrorist behavior not amenable to explanation by other social science methodologies. Although most terrorist acts are comparatively cheap, involving as they generally do small numbers of participants and inexpensive weaponry, the resources at a terrorist group's disposal necessarily are limited relative to the many and varied options available for accomplishing its purposes. As a result, a terrorist group faces the economic problem of allocating money and manpower cost-effectively, both across potential targets and over time, so as to maximize the expected net returns to its violent campaign. Viewing terrorism as primarily rational in the sense of economics generates testable predictions about how terrorist groups will go about solving that optimization problem and, in particular, how they will respond to changes in the anticipated benefits and costs of terrorist activity. The theoretical predictions of the rational-actor model have been of distinct value in understanding the consequences of public policies designed to parry terrorist threats.

It is important to recognize, in that regard, that terrorists enjoy a number of strategic and tactical advantages over government policymakers charged with the responsibility of protecting their homelands against terrorist attacks. Target selection is among the chief of these comparative advantages. Because nations cannot safeguard people and property everywhere, terrorist groups can strike where countermeasures remain feeble. Terrorist groups are wellpositioned to exploit existing vulnerabilities because they typically are better informed about the 
strengths and weaknesses of a nation's defensive measures than governments are about the sizes, locations and effectiveness of terrorist cells, and they are organizationally less hierarchical, operationally more independent and, hence, more nimble and innovative in acting than public law enforcement and counterterrorism agencies are in reacting (Hirshleifer 1991; Sandler 2005b).

Governments, especially democratic governments, are constrained further in their responses to terrorism by the force of public opinion. Indeed, in addition to creating a climate of fear, terrorist groups may be able to achieve their goals by provoking governments into adopting repressive countermeasures that undermine civil liberties or simply disrupt daily life so much so that the citizenry turns its ire, not against the terrorists themselves, but against the governing regime. Extensive security precautions may also serve a terrorist group's cause by contributing to the public's perception of its power (Crenshaw 1990, p. 19).

Terrorists rationally search out "soft" targets and consequently respond in predictable ways to antiterrorist measures. ${ }^{7}$ Consistent with rational-choice theory, the historical record suggests that terrorist groups substituted kidnappings and assassinations of foreign-service personnel for embassy bombings when steps were taken to protect embassies against such threats. Similarly, terrorist hijackings of commercial aircraft declined in favor of other hostagetaking missions after airport security was tightened by installing metal detectors to screen boarding passengers (Landes 1978). ${ }^{8}$ In an age of transnational terrorism, defensive actions taken by one country may merely induce terrorists to transfer their attacks to less-secure venues abroad (Sandler 2005a, b). The available empirical evidence lends support to these and other predictions of the theory (Enders, Sandler and Cauley 1990; Enders and Sandler 1993, 1995, 2004). 
Terrorism, it is important to emphasize, does not arise in a vacuum. It emerges from inter-group conflict - over land or other physical resources, over control of the levers of political power, including patronage, and so on. "Gain (or avoidance of loss) is the common reason for undertaking warfare" (Tullock 1974, p. 87); terrorism differs from war in means (and perhaps scale), but not in ends. Inter-group conflict, whether real or imagined, may supply the conditions necessary for overcoming free-riding by terrorist group members. Russell Hardin (1995, p. 5), in fact, argues that individual "self-interest can often successfully be matched with group interest" (i.e., collective action is easier to organize) when a group's "benefit comes from the suppression of another group's interest."

\subsection{Terrorist "waves"}

Terrorism is age old, going back as far as the Jewish Zealots (sicari), who were active during Rome's occupation of Palestine (Laqueur 1999, pp. 10-11). In more recent times, it was given impetus by Robespierre's régime de la terreur (June 1793-July 1794) and, indeed, Edmund Burke has been credited with adding the word terrorist to the English lexicon in his Reflections on the Revolution in France, which railed against the "thousands of those Hell hounds called Terrorists ... let loose on the people" by the Jacobins, regularly assisted by Dr. Guillotin's famous invention (quoted in Hoffman 1998, p. 17). ${ }^{9}$

Despite its murky origins, contemporary students of the history of terrorism tend to trace its modern beginnings to the founding, in 1878, of Narodnaya Volya ("People's Will" or "People's Freedom"), apparently the first group systematically to replace the "propaganda of ideas" with "propaganda by deed", a strategic reorientation attributed to Carlo Pisacane, who perished forty years earlier during an unsuccessful Italian revolt against Bourbon rule (ibid.; Rapoport 2004, pp. 50-52). Narodnaya Volya did not, however, engage in a campaign of 
indiscriminant violence. Like the Thermidorian Reign of Terror before it, Narodnaya Volya was organized, deliberate and methodical in selecting its victims, most of whom were prominent Russian government officials, culminating in the assassination of Tsar Alexander II on 1 March 1881 (Hoffman 1998, pp. 17-18).

Despite inevitable differences in the identities, objectives and tactics of the many terrorist groups that would come afterwards, David Rapoport, for one, nevertheless argues that Narodnaya Volya launched the first of what he identifies as the four waves of modern terrorism, an "anarchist wave" that spread from Russia to Western Europe, the Balkans and Asia, reaching its "high point ... in the 1890s, sometimes called the "Golden Age of Assassination"” (Rapoport 2004, p. 52). The wave of anarchist terrorism eventually found its way to the United States, where, in September 1901, President William McKinley fell to an assassin's bullet.

In what follows, I adopt Rapoport's useful concept of terrorist waves to organize the history of terrorism since 1945. Beginning with the wave of "post-colonial" or "anti-colonial" terrorism that originated in the 1920s and continued for two decades beyond the Second World War's end, the discussion moves on to the wave of "New Left" terrorism that swept the globe during the middle of the second half of the twentieth century, and from there to the wave of "religious", mostly Islamist, terrorism ignited by the Iranian Revolution. Arranging the history of terrorism in this way is not meant to imply that every group active at any one time wore the same label. History is messy. Groups formed around "anti-colonial", "New Left" and "religious" ideologies appear in all three terrorist waves; the cycles of violence overlap one another. Terrorism nevertheless has changed character over time in ways distinctive enough to warrant separate treatment. 
There is a unifying theme, however. As argued in section 6 below, much of the terrorism of the post-Second World War period originated in the grievances of ethnic and religious groups marginalized politically in artificial nation-states created by the colonial powers in the late nineteenth and early twentieth centuries. Nationalist and ethnic separatist movements, aimed at achieving independence and self-determination, certainly played significant roles in motivating the first and third of the terrorist waves to have emerged in the period since 1945. To the extent that the left-wing terrorists of the second wave claimed solidarity with the "oppressed peoples" of Palestine and other Third World nations, the arbitrariness of the borders imposed on Central Asia, the Balkans and the Middle East, reinforced by illiberal constitutions and despotic rulers, can be said to be root causes of all three waves of modern terrorism.

There are exceptions, of course. The events of 1914-1922 do not explain the activities of today's Latin American terrorists, many of whom are involved heavily in drug trafficking. Nor do they have anything to do with the violence perpetrated by Japan's Aum Shinriyko and likeminded "cult" terrorist groups, the Tamil Tigers of Sri Lanka, or the Sudanese People's Liberation Army. In what follows, it is nevertheless argued that the history of terrorism since 1945 is in large part a consequence of the decisions taken immediately in the wake of the First World War and of the unkept promises made by the superpowers both then and forty years on.

\section{Terrorism in the service of national liberation}

[A]11 these panslavisms and nationhoods - it's all too old to be new. — Fyodor Dostoevsky ([1872] 1994, p. 36)

The Second World War gave new life to a "post-colonial" or "anti-colonial" wave of terror that already was underway in the 1920s. It lasted for roughly 20 years beyond war's end, waned for a brief period during which left-wing terrorist groups held center stage, and reemerged with a 
vengeance in the last decade of the twentieth century. This first post-war wave of terrorist activity saw terror placed chiefly in the service of nationalism and ethnic separatism, decisively so in the creation of the new states of Algeria, Cyprus, Ireland and Israel, among others (Rapoport 2004, p. 53).

\subsection{Beginnings}

The origins of terrorism motivated by nationalist goals, or at least that of the twentieth century's second half, can be traced directly to the decisions taken by the victors at the Paris Peace Conference that concluded the First World War (Rapoport 2004, p. 52). Woodrow Wilson, who had reluctantly and belatedly entangled the United States in European affairs and mired American troops in the mud of Belgium and France, naïvely thought that the "War to End all Wars" had, by smashing the Ottoman Empire beyond repair, supplied a golden opportunity for nation-building under the principle of "self-determination", a term he may have coined. Sailing aboard the George Washington with the American delegation to the peace conference, Wilson proclaimed, "We say now that all these people have the right to live their own lives under governments which they themselves choose to set up" (Macmillan 2002, pp. 3, 11). That credo had been memorialized in the president's famous "Fourteen Points", which framed the position America would take at Paris. Point number five sweepingly called for

a free, open-minded, and absolutely impartial adjustment of all colonial claims, based upon a strict observance of the principle that in determining all such questions of sovereignty, the interests of the populations concerned must have equal weight with the equitable claims of the government whose title is to be determined. (Quoted in ibid., p. 495)

Wilson's other points addressed more specific issues that would vex the conferees in clearing the political wreckage of global conflict. These included appeals for "a readjustment of the frontiers of Italy ... along clearly recognizable lines of nationality"; "the freest opportunity of 
autonomous development" for the peoples of Austria-Hungary; "the relations of the several Balkan states to one another determined ... along historically established lines of allegiance and nationality", accompanied by "international guarantees" of the states' "political and economic independence and territorial integrity"; "secure sovereignty" for the Turkish portions of the prostrate Ottoman Empire, but also "an undoubted security of life and an absolutely unmolested opportunity of autonomous development" for other nationalities then under Turkish rule; and an "independent Polish state" created from "the territories inhabited by indisputably Polish populations...." Wilson's new world order was to be supervised by "a general association of nations ... formed under specific covenants for the purpose of affording mutual guarantees of political independence and territorial integrity to great and small states alike" (ibid., p. 496). As part of its responsibility, this League of Nations would accept "mandates" for managing the affairs of peoples not yet ready for full sovereignty, but preparing them "by friendly counsel" for eventual statehood.

In the event, unwilling to compromise, weakened by illness - the Spanish 'flu, not, as commonly believed, a minor stroke (Barry 2004, p. 387) - and unable to slake French thirst for vengeance against the Hun, an exhausted Wilson returned home from Paris to serve out his presidential term and, after a brief flurry of domestic politicking on behalf of American participation in the League of Nations, to watch in near silence as the Republican-dominated US Senate refused to ratify the Treaty of Versailles (ibid., pp. 487-492). Crippled by America's withdrawal from the world stage and fulfilling the terms of the secret Sykes-Picot Agreement of 1916, the League's mandates in the non-European parts of the defeated German, AustroHungarian and Ottoman empires were divided between Britain and France. The latter was granted mandatory powers in Syria and Lebanon; the former assumed mandates for Egypt, where 
she had ruled "temporarily" for decades (Fromkin 1989, p. 415), the Sudan, Palestine, Transjordan, Iraq (then known as Mesopotamia) and much of the territory now comprising the Gulf States.

In a preview of things to come after the Second World War, local resistance to the mandatory powers surfaced in short order as former imperial subjects, aggrieved by unbidden administration from London or Paris, began demanding the home rule Wilson had promised to them. Disorder began in Egypt, where "the principal British fantasy about the Middle East - that it wanted to be governed by Britain, or with her assistance - ran up against a stone wall of reality" (ibid., p. 420). Apparently "unaware of the implications of the profound social and economic changes brought about by the war; the new classes and ambitions that had emerged, the new interests, the new resentments, and the new sources of discord and disaffection", British military personnel and civil servants became the human targets of anti-colonial sentiment, culminating "on 18 March [1919] in the murder of eight of them - two officers, five soldiers, and an inspector of prisons - on a train from Aswan to Cairo" (ibid., pp. 418-419).

Rebellion against the mandatory powers also enveloped Afghanistan. The assassination of the Emir on 19 February 1919 triggered a round of tribal infighting that in due course pulled Britain into a Third Afghan War (ibid., pp. 421-23). By 1920, violence had erupted across virtually all of the Middle East and Central Asia. "In the summer of 1919, three young British captains were murdered in Kurdistan"; before the next spring arrived, Arab raiding parties in Mesopotamia (Iraq) had killed six British officers and had executed two political officials taken as hostages. British outposts were overrun throughout the region; jihad was proclaimed against Britain in Karbalah and, in an act condemned in newspaper headlines as "Arab Treachery", a sheikh serving as legendary Colonel Gerald Leachman's host at a meeting of tribal allies, 
ordered him shot in the back after persuading him to release his armed escort. "How much longer", The Times demanded on 7 August 1920 (ibid., p. 452), "are valuable lives to be sacrificed in the vain endeavor to impose upon the Arab population an elaborate and expensive administration which they never asked for and do not want?"

Roused by the Balfour Declaration of 1917, which expressed the British government's willingness to look favorably on proposals leading to the establishment of a Jewish national homeland, the interwar period also witnessed the beginnings of the bloodshed that would engulf Palestine, Transjordan and Lebanon for the remainder of the century and beyond. The Irgun Zvai Le'umi, led by future Israeli Prime Minister Menachem Begin, was born in Palestine "in the late 1930s as the armed wing of the right-wing Revisionist Party” (Laqueur 1999, p. 22). Other groups active in the years following the First World War included the Irish Republican Army, founded in 1916, although not initially as a terrorist organization (Rapoport 2004, p. 48); Russia’s so-called Black Hundred, which engaged in a terror campaign against the Bolsheviks; the German Freikorps, small bands of students and former soldiers formed for similar purposes, whose most prominent victims were, in 1919, Rosa Luxemburg and Karl Liebknecht, two heroes of that country's abortive socialist revolution, followed, in 1922, by the German foreign minister Walter Rathenau; and the Ustasha, a terrorist group supported by Benito Mussolini in its pursuit of Croatian national independence and responsible for the double murder of King Alexander of Yugoslavia and French prime minister Barthou during their joint meeting in Marseilles in April 1934 (Laqueur 1999, pp. 21-22).

Nationalism and ethnic separatism also were the prime motives underlying the terrorism that emerged in the immediate wake of the Second World War. The promises of selfdetermination contained in Woodrow Wilson's Fourteen Points had been reaffirmed before Pearl 
Harbor in an eight-point document signed by Franklin Roosevelt and Winston Churchill when they met on a warship off the coast of Newfoundland in 1941. Point two of the so-called Atlantic Charter "declared unequivocally that neither Britain nor the United States desired to 'see ... territorial changes that do not accord with the freely expressed wishes of the peoples concerned"” (Hoffman 1998, pp. 46-47). Point three committed both countries to "respect the right of all peoples to choose the form of government under which they will live" (ibid., p. 47). Those principles subsequently were included in the Declaration of the United Nations, accepted by the two allies on 1 January 1942, and later signed by all countries at war with Germany (ibid.). Colonial subjects once again were given reason to expect the return of peace to at the very least initiate processes to terminate foreign rule and to lay the foundations for transitions to national independence. It turned out, though, that the promises made by some of the signatories to the Atlantic Charter and to the UN Declaration were promises "they had no intention of keeping" (ibid.). Winston Churchill, for one, never meant the principle of self-determination to "apply either to Asia or Africa, especially not to India and Palestine, but only to those peoples in hitherto sovereign countries conquered by Germany, Italy and Japan” (ibid.). But, as Bruce Hoffman (1998, p. 47) observes, "the damage had already been done."

What followed was a renewal of the anti-colonial wave of terror that marked the early interwar years in the Middle East. Owing to the technological advances in weaponry spurred by the Second World War, the terrorists were better armed this time around. Emboldened by the weakening of the European colonial powers as war shifted the locus of global supremacy toward Washington, terrorism in the service of national liberation extended its reach across North Africa, the Mediterranean and Asia. On the last of these continents at least, the great military historian Basil Liddell Hart traces the emergence of nationalist movements to the British Army's 
collapse at Singapore on 15 February 1942: "Its easy capture ... was shattering to British, and European, prestige.... The white man had lost his ascendancy with the disproof of his magic. The realization of his vulnerability fostered and encouraged the post-war spread of Asiatic revolt against European domination or intrusion” (Liddell Hart [1971] 1999, p. 233).

\subsection{Algeria}

The postwar wave of terror began in Algeria, as we have seen. By 1954, V.E. Day's violence at Sétif had evolved into full-blown civil war as local aspirations for national independence ran head-long into the strong opposition on the part of Algeria's considerable European population to any thought Paris might have of abandoning its authority (Rapoport 2004, p. 53). Similar conflicting aspirations produced terrorism in Northern Ireland, where the preferences of Ulster's Anglican majority for remaining British clashed with the Catholic minority's wish for republican union with the South, and in Cyprus, where the Turkish community did not want to be ruled from Athens, which was the aim of the Greek terrorist group, Ethniki Organosis Kyprion Agoniston (EOKA), and where the British wanted to maintain military bases to support operations in the Middle East (ibid.).

During the first two years of Algerian civil war, the anti-colonial terrorist campaign conducted by the Front de Libération Nationale (F.L.N.) deliberately had been non-lethal. It principally targeted symbols of colonial rule - bombing French government offices and buildings, military facilities and police stations - rather than human beings (Hoffman 1998, p. 62). Towards the middle of 1956 , however, with "precious few tangible achievements to show for its efforts", and in reaction to the growing effectiveness of France's countermeasures, culminating in the execution by guillotine of two of its operatives, the F.L.N. changed strategies in favor of mass urban terror. 
Within 72 hours of announcing that 100 Frenchmen would be killed for every martyr to the F.L.N. cause, 49 European civilians had been gunned down. In August, the group orchestrated the coordinated bombings of three public venues frequented by the colons (or pieds noir, as they were by then often called): a seaside milk bar, an Algiers cafeteria popular among European university students, and the downtown Air France terminus. Three people were killed and some 50 injured in the attacks, the first lethal round in what would become an ever-morevicious cycle of terrorist outrage and heavy-handed French repression. On 28 December 1956, the French mayor of Algiers was assassinated by F.L.N. cadres. The mayor's assassination triggered anti-Muslim rioting and that, in turn, provoked a new round of F.L.N. killings. One month later, the F.L.N. declared a general strike - timed to coincide with the convening of a UN General Assembly discussion of the Algerian conflict - and launched a two-week campaign of bombing, expanding its targets to include popular bars and restaurants, crowded city streets and sports stadiums, killing 15 people and wounding 105 others in what would become known as the "Battle of Algiers" (ibid., pp. 57, 62-63).

In response, France redoubled her efforts to maintain order in the city under the leadership of General Jacques Massu, commander of the 10th Parachute Division and a veteran of Indochina. Although Massu eventually "won” the battle for control of Algiers, his strategy for doing so, which relied on gathering intelligence to identify and track down terrorist leaders, encouraged abuses that would foreshadow Abu Ghraib: "Torture of both terrorists and suspected terrorists became routine" (ibid., p. 63; emphasis in original). The normally apathetic Arab "street" was driven into the arms of the F.L.N. by the French Army's brutality; public opinion in metropolitan France turned sharply against continuation of colonial rule. Massu's victory was 
Pyrrhic. Five years later, France withdrew from Algeria and granted independence (ibid., pp. 6364).

\subsection{Cyprus}

A series of similar events played out in Cyprus, where, by 1955, the EOKA had succeeded in throwing the island into complete chaos. Never more than 400 active terrorists strong, the Greek Cypriot organization employed hit-and-run tactics against the much larger British security force deployed on station, managing to kill over the next four years an average of two soldiers or policeman every week. The British never were really in the game, constantly kept off balance and unable to bring their superior military strength effectively to bear in countering a small, cohesive group that did not seek outright victory, but "to rely on dramatic, well-orchestrated and appropriately timed acts of violence to focus international attention on the situation in Cyprus and ... the demand for enosis - unification with Greece" (ibid., pp. 57-58). Like the F.L.N., the EOKA concentrated its attacks on the island's urban centers, where incidents would command immediate media attention and where it could hamstring British responses by forcing troops to be dispersed citywide on static guard duty missions at scores of potential terrorist targets, perhaps none of which would be hit on any given day (ibid., p. 58).

The asymmetry between the target-rich EOKA and the target-poor, nearly 40,000member British security force stationed on Cyprus ultimately worked in the former's favor. ${ }^{10}$ Foreshadowing the relationship later forged between the IRA and Sein Fein, the EOKA's campaign of violence also benefited significantly from close coordination with Archbishop Makarios III, who simultaneously pursued the goal of enosis through diplomatic channels. Britain reacted to the terrorists" "apparent ability to strike anywhere, anytime" and to the growing "public frustration caused by disruption to daily life" by interning and then exiling 
Makarios to the Seychelles in 1956. He was allowed to return to Cyprus two years later, however, to fulfill a Greek Cypriot condition for participation in multilateral peace talks. Those talks eventually produced agreement, in February 1959, granting Cyprus independence, if not unification. Archbishop Makarios became the new nation's first president (ibid., pp. 59-60).

\subsection{Israel}

Celebrated by Leon Uris in his novel, Exodus, and in David Lean's film of the same title, the anti-British violence that accompanied the birth of Israel is perhaps the most well-known of the terrorist campaigns that followed Allied victory in the Second World War. The campaign was spearheaded by the Irgun, which, as noted previously, first appeared on the Palestinian scene in the 1930s. It recommenced operations against Britain's security forces, charged by London with the ultimately futile task of controlling immigration by tens of thousands of Jews fleeing Nazi Holocaust and war-devastated Eastern Europe, in February 1944. Menachem Begin, who had assumed command of Irgun three months earlier, recognized that his group was hopelessly outgunned. He therefore aimed "not to defeat Britain militarily, but to use terrorist violence to undermine the government's prestige and control of Palestine by striking at symbols of British rule" (ibid., p. 50). The Irgun announced the end of its wartime suspension of hostilities against Britain with coordinated bombings of immigration offices in Jerusalem, Tel Aviv and Haifa. It followed that announcement up over the next two years with a series of carefully planned attacks on British land registry offices as well as on the security forces themselves. The apogee of the Irgun's terrorist campaign was reached in July 1946, when the group succeeded in placing explosives under the wing of Jerusalem's King David Hotel housing both the British government's secretariat and the headquarters for Britain's security forces in Palestine and 
Transjordan. Ninety-one people died and 45 others were injured in what still ranks among the twentieth century's most lethal terrorist incidents (ibid., pp. 50-51).

A radical offshoot of Irgun, known by the acronym Lehi (Lohameni Herut Yisrael, or "Freedom Fighters for Israel”), which the British called the Stern Gang (ibid., p. 28; Rapoport 2004, p. 54), broke with Begin's stated policy, the King David Hotel bombing notwithstanding, ${ }^{11}$ of not deliberately targeting civilians. Led by another future Israeli Prime Minister, Yitzhak Shamir (Laqueur 1999, p. 23), Lehi engaged in a strategy of political assassination.

Both groups in time achieved their goal of a separate Jewish state by provoking Britain into adopting increasingly repressive countermeasures. Each terrorist outrage produced a fresh round of retribution and reprisal, as exemplified by the Irgun's hanging in July 1947 of two British sergeants following the execution of three convicted Jewish terrorists (Hoffman 1998, p. 54). Taking place against the backdrop of hearings on the country's future being conducted that same summer by the UN's Special Committee on Palestine (UNSCOP) - hearings before which Begin was twice called to testify - the hangings inflamed British public opinion. Newspaper photographs of the two corpses supplied graphic evidence, if more was needed after three years of violence and the deaths of some 150 British soldiers, of the security force's inability to maintain order despite overwhelming numerical superiority. And so, the game may already have been up by the time the UN committee issued its report unanimously recommending the immediate end of British rule and Palestinian independence. Arthur Creech-Jones, the colonial secretary, announced in September 1947 that Britain would no longer take responsibility for governing Palestine; on May 15th of the next year, the State of Israel was proclaimed (ibid., pp. $52-56)$.

\subsection{Lessons}


The main lesson of the first post-Second World War wave of terrorism is that terrorism can succeed. The violence directed against occupying colonial forces by the F.L.N., the EOKA and the Irgun was instrumental in securing national independence for Algeria, Cyprus and Israel. These three historical examples show how relatively small groups of urban guerillas, though overmanned and outgunned by regular armies on the ground, can demoralize great empires by waging campaigns of carefully planned attacks on targets inevitably left pregnable by the larger, but less flexible forces arrayed against them. Terrorists do not have to defeat their opponents militarily; they only have to avoid losing (Hoffman 1998, p. 52).

A second lesson is that a terrorist group's cause can be advanced considerably by repressive countermeasures. Combined with the "psychological impact" produced by tarnishing the image of a government unable to maintain order (ibid. p. 53), terrorists can shift public opinion toward their cause - or turn it against their adversaries - by goading local governmental officials and security personnel into responding heavy handedly, disrupting the normal daily lives of the civilian population and meeting each terrorist atrocity with an even greater outrage. Exploiting public opinion on both margins requires publicity. Success in choreographing violence so as to gain the attention of external audiences was one of the most significant achievements of the leaders of the terrorist wave of the late 1940s and 1950s, who were the first to recognize its potential (ibid., p. 65). It was a lesson taken to heart by their successors.

\section{Left-wing terrorism}

Oh, my friends, ... you cannot imagine what sorrow and anger seize one's whole soul when a great idea, which one has long and piously revered, is picked up by some bunglers and dragged into the street, to more fools like themselves, and one suddenly meets it in the flea market, unrecognizable, dirty, askew, absurdly presented, without proportion, without harmony, a toy for stupid children!

— Fyodor Dostoevsky ([1872] 1994, pp. 25-26) 
During the 1960s, opposition to the Vietnam War produced a wave of "New Left" terrorism, as radical groups in Europe, Latin America and the United States, often aided and abetted by the Palestine Liberation Organization, undertook campaigns of political kidnappings, assassinations and bombings in furtherance of vague Marxist-Leninist-Maoist political agendas and woolly headed demands for "social justice". Penetration of these groups by undercover agents, the capture and arrest of key terrorist-group leaders and the collapse of the Soviet Union, which put paid to the radicals' never-very-well-articulated purposes, combined to bring the second post-war wave of terrorism to an end. Its remnants nevertheless survive in parts of Central and South America as well as in South Asia.

Dostoevsky's "stupid children" - "foolish" is perhaps a better term - were off at university in the 1960s. Radicalized by America’s growing involvement in Vietnam and schooled in the values of a drug-laced counterculture that permeated the halls of academe from the Sorbonne to Berkeley, many young, mostly white and middle-class men and women suddenly discovered themselves, in fellow feeling, first, for the Viet Cong and, later, for the Palestinians, to be "the vanguard of the exploited and oppressed Third World" (Laqueur 1999, p. 27). The most committed of these progressive cadres turned their pacifist sympathies for the downtrodden into rage against the imperialist "system" that oppressed them.

\subsection{Germany and Italy}

Organized by Andreas Baader and Ulrike Meinhof in the West Germany of the late 1960s, the Red Army Faction (RAF) - an "army" whose strength at most numbered perhaps three dozen (Laqueur 1999, p. 27) - was the first of the left-wing terrorist groups to surface in the post-war era. Also known as the Baader-Meinhof Group, the self-styled revolutionaries carried out a series of bank robberies, burned several department stores, and murdered a number of bankers, 
industrialists and judges, their most prominent victims being the Attorney General, Hans-Martin Schleyer, and Siegfried Buback, the head of the Berlin Supreme Court (ibid. p. 28; Rapoport 2004, p. 57). The RAF's first, and perhaps most notorious, actual terrorist act was to bomb the officers' mess of the US Fifth Army Corps at Frankfurt, killing one person and injuring 13 others. That attack was later justified at the trial of one of the RAF's leaders as befitting retribution for the mining of the North Vietnamese harbor at Haiphong by the US Air Force (Hoffman 1998, p. 81).

Terrorist groups with similar ideological motivations soon appeared in Italy, Belgium and France. The Italian Red Brigade (Brigate Rosse) was formed in 1970. It was much more active than the RAF, engaging in some 14,000 terrorist attacks in its first ten years of existence. Like the RAF, the Red Brigade mainly targeted prominent public officials, including judges and jurors, concentrating its attacks in Rome and in Italy's industrial regions (Laqueur 1999, pp. 2829). Frequently applying non-lethal force - "kneecapping" was one of the group's favored tactics - the Red Brigade nevertheless nearly succeeded in bringing Italy's legal system to a standstill (ibid., p. 29). The group then overreached, first, by expanding its list of targets to include journalists and labor union officials and, second, by kidnapping and killing the Italian Prime Minister, Aldo Moro, afterwards dumping his body in the street (ibid., p. 29; Rapoport 2004, p. 57). Moro's brutal 1979 murder, committed because he refused to enter hostage negotiations (Rapoport 2004, p. 57), in particular turned public opinion strongly against the Red Brigade, eliciting outrage even from the Italian Communist Party, which concluded that terrorism was undermining its political prospects. That widely condemned act backfired doubly by energizing the government's counterterrorism efforts. As a result of the post-Moro crackdown, by 1982 some 1400 members of the Red Brigade had been arrested, many of whom, promised leniency in 
return for cooperation (Ferracuti 1990, p. 62) and christened the pentiti, disavowed their former comrades and assisted the police in identifying the group's leaders, only one of whom still remained at large in 1984. The Red Brigade soon passed into history (Hoffman 1998, p. 29).

\subsection{Palestinian complicity}

Although both Andreas Baader and Ulrike Meinhof likewise had been arrested (and both had committed suicide while in prison), ${ }^{12}$ the RAF soldiered on under new leadership, as did its sister German terrorist organization, the Second of June Movement, infamous for its attack on a Jewish synagogue on the anniversary of Kristallnacht (Rapoport 2004, p. 59). Left-wing terrorism in Europe and Japan was kept alive during the 1970s and 1980s in part owing to Palestinian assistance. Indeed, from the late 1960s onward, terrorist groups routinely have shared personnel, intelligence, logistics, training camps and resources (Alexander and Pluchinsky 1992; Hoffman 1998). As early as 1968, the Popular Front for the Liberation of Palestine (PFLP), a group operating under the umbrella of the PLO, fresh from its successful hijacking of an El Al commercial aircraft, had begun inviting terrorist groups from other nations to its Jordanian training camps (Hoffman 1998, pp. 67, 82). West German terrorists accepted the PFLP's invitation for the first time in 1969; the following year another group of Germans, including the RAF's two founders, made its way to Jordan via Beirut (ibid., p. 82).

The training and indoctrination the Palestinians provided to the West Germans paid off handsomely for both parties, especially so after the Vietnam War came to ignominious end in 1975 and the PLO replaced the Viet Cong as the chief object of left-wing sympathies (ibid., pp. 81-82). German terrorists reportedly furnished logistical support to Black September, assisting that terrorist group in its massacre of Israeli athletes in their dormitory at the 1972 Munich Olympic Games - a drama played out before the cameras of ABC Sports, whose televising of 
occasional and tensely anticipated balcony appearances by a shadowy figure wearing a white hat riveted the world's attention and transformed Munich into a "spectacular publicity coup" for the Palestinians (ibid., p. 73). ${ }^{13}$ Yassir Arafat's al-Fatah organization in turn supplied the RAF with weapons. Operations conducted by combined teams of German and Palestinian terrorists were responsible for disrupting an OPEC meeting in Vienna in 1975 and kidnapping some of its ministers, as well as for the hijackings of two commercial airliners, one an Air France flight to Entebbe, Uganda, the next year, the other a Lufthansa jet en route to Somalia in 1977 (ibid., p. $83)$.

Palestinian assistance also helped sustain the Japanese Red Army (JRA), which after a brief but eventful terrorist career, found asylum in Lebanon. JRA operatives committed murders, hijacked a commercial Japanese aircraft, and sabotaged a Shell oil refinery in Singapore and the French embassy compound in The Hague. They linked up from time to time with Carlos ("The Jackal") and joined forces with their Palestinian benefactors to participate in the massacre at Tel Aviv's Lod Airport (Laqueur 1999, p. 30).

By 1985, the collaboration between the Germans and the Palestinians had flourished so much so that the RAF joined forces with Action Directe (AD), its counterpart leftist terrorist organization in France. The leaders of the two groups envisioned forming an umbrella group on the PLO model that would include a resuscitated Red Brigade and Belgium's Communist Combatant Cells (CCC) for the purpose of launching a wave of "Euroterrorism" targeting NATO installations and personnel. That vision never became reality, however. As it had in Italy, effective police work leading to the arrests of leading members of the French and Belgian groups crippled the terrorists' grand strategy. Perhaps as important, monumental events taking place behind the Iron Curtain - Gorbachevian glasnost and perestroika, the rise of the Solidarity labor 
movement in Poland, and so on - progressively undermined the ideological foundations of the European left-wing terrorist groups. Those foundations collapsed fully in 1989 when the Berlin Wall came down, not least because German reunification eliminated the terrorists' ready-to-hand sanctuary in the East. The RAF disbanded for good in 1992, although the group's true-believing holdouts, acknowledging that they were "stuck in a dead end", did not announce its demise officially until April 1998 (Hoffman 1998, pp. 83-84; Pillar 2001, p. 42).

\subsection{The Americas}

Left-wing terrorism was not confined to Europe and Japan in the middle decades of the postSecond World War period; it was a global phenomenon. In the United States, the 1960s gave rise to, among others, the Weathermen, the Black Panthers and the Symbionese Liberation Army (SLA). The last two groups, embracing the Maoist dictum that "power grows out of the barrel of a gun", adopted a modus operandi for carrying out their racist "armed struggle" indistinguishable from that of ordinary criminals, robbing banks and committing the occasional murder (Laqueur 1999, pp. 29-30), most notoriously so in the SLA's case with the assistance of kidnapped and converted newspaper heiress, Patty Hearst. More like their left-wing European terrorist comrades, the Weathermen, a splinter faction of the Students for a Democratic Society (SDS), pursued an anti-imperialist agenda, specializing in bombing institutional symbols of what they viewed as the capitalist, fascist, war-mongering "establishment". Over the course of a four-year campaign of terror in the late 1960s and early 1970s, launched on 7 October 1969 by blowing up a police monument in Chicago (Sprinzak 1990, p. 65), "the Weathermen, later named the Weather Underground, then the Weather People", were responsible for 19 bombing incidents at corporate offices, New York City police headquarters, the US Capitol, the Pentagon (Gurr 1990, p. 88), military induction centers (Sprinzak 1990, p. 77), and a Defense Department research 
center at the University of Wisconsin. However, the group's most deadly terrorist "incident" occurred when "three leaders of the organization blew themselves up in a New York townhouse while manufacturing a bomb" (ibid.).

Often modeled on Cuban revolution - or directly supported by Fidel Castro's regime leftist terrorism also swept across much of Latin America in the late 1960s and 1970s. In Uruguay, the Tupamaros robbed banks and kidnapped political figures with the aim of disrupting the functioning of civil government. The group's most effective strategy apparently was to intimidate the Uruguayan police by assassinating some of its officers, including the head of the force's special counterterrorism unit, and kidnapping their family members (Tullock 1974, pp. $56-57)$.

Similar terrorist campaigns, but on a much more massive scale, were waged by two Argentine terrorist groups, the Peronist Montoneros, who announced their presence by assassinating ex-President Aramburu in May 1970, and the more doctrinally left-wing ERP. The first of these groups, for which bombs were the weapon of choice, initially targeted foreigners (or Argentinians representing foreign economic interests), but gradually expanded its victim list to include the army, the police, politicians and labor union leaders, along with any innocent bystanders who happened to be within range. At its campaign's zenith, in 1975-1976, the Montoneros committed 646 political murders and attacked military installations in a number of provincial cities. In both countries, terrorism triggered military takeovers of civilian government and eventual suppression of terrorist activity by the generals. Repressive measures also ended the three-year Brazilian "urban guerilla" terrorist campaign launched in the 1960s by Carlos Marighella, who was gunned down by police in an ambush in São Paulo in November 1969. 
Venezuela and Columbia likewise witnessed waves of left-wing urban terror during the same period, as did most other Latin American nations (Laqueur 1999, pp. 25-27).

\subsection{Turkey}

Supported by Bulgaria and other Soviet satellites, left-wing terrorists operating out of university safe-havens struck targets in major Turkish cities. Right-wing groups receiving assistance principally from Syria and finding their own sanctuaries in local mosques quickly emerged to counteract the terrorists of the left. Both wings of the Turkish terrorist movement of the 1970s seem to have been animated by generalized hostility to the democratization and westernization of Turkish institutions underway since the Ottoman Empire's end (ibid., p. 31). Above all, however, it is to the grievances of Turkey's Armenian minority that the terrorism of the time can most directly be traced. Two such terrorist groups, the Armenian Army for the Secret Liberation of Armenia (ASALA) and the Justice Commandos of the Armenian Genocide (JCAG), emerged from the rubble of Lebanese civil war in 1975. Also schooled in Palestinian training camps and, in the ASALA's case, generously supplied with arms and aided in other ways by the PFLP, the two groups had three shared goals: (1) to exact revenge for Turkey's expulsion of their forebears, in 1915, from the Armenians' traditional homelands in eastern Turkey to Syria and Iraq, an episode during which 1.5 million souls are thought to have perished; (2) to force the Turkish government to acknowledge responsibility for Armenian genocide; and (3) to compel payment of reparations to the survivors and their descendants (Hoffman 1998, pp. 76-77).

Even before the Armenian terrorist groups became active, however, the police's inability to cope with widespread terrorist violence prompted Ankara to impose martial law in 1971. Order had for the most part been restored three years later, martial law was lifted and a general amnesty was declared. "That turned out to be a costly mistake", in Walter Laqueur's (1999, p. 
31) judgment. Terrorist activity soon resumed with a vengeance. In 1978-1979, some 2400 political murders were committed in Turkey. The threat of open warfare in the streets prompted the army to again take control in October 1980. Rounding up 75,000 terrorist suspects and seizing more than 730,000 weapons, the generals succeeded in returning Turkey to a state of comparative normalcy within a few days (ibid.).

The army's tough countermeasures did not fully put an end to the wave of violence perpetrated by the Armenian terrorists, though. Adhering explicitly to a Marxist-Leninist ideology, the ASALA was by and large indifferent to the identities of its targets. It bombed the Turkish airline's ticket counter at Paris's Orly Airport in July 1983, killing seven and injuring 56. One month later, the group killed nine more people and wounded 78 others in an attack at Ankara's Esenboğa Airport; an ASALA assault on Istanbul's Grand Bazaar, also in August, claimed another 29 casualties, including two dead. The JCAG, by contrast, pursued a more conventional nationalist-separatist strategy of spreading terror by assassinating Turkish government officials and striking with non-lethal force at symbols of Turkish hegemony. All told, Armenian terrorists murdered more than 40 Turkish civil servants and members of their families in the decade after the two groups' founding (Hoffman 1998, p. 77).

\subsection{Spain, the Netherlands and Ireland}

Much the same blends of leftist ideology and ethnic separatism animated, at least initially, the terrorist activities of Spain's Euskadi ta Askatasuna (ETA), which translates as "Basque Nation (or Fatherland) and Liberty", the militant South Moluccan expatriates in the Netherlands, and the Irish Republican Army, all of which waged campaigns of violence from the late 1960s on.

Effectively suppressed by General Franco, although they did manage to derail a Spanish train in 1961 while he was still in power, the high tide of ETA terrorism came in 1978-1980. 
Grounded in the injustices felt by Spain's Basque minority, aggrieved by being ruled from Madrid and yearning for the creation of a separate Basque state, the ETA succeeded in assassinating Franco's successor, Admiral Carrero Blanco, and then added considerably to its victim list over the next two years by committing another 170 political murders (Laqueur 1999, p. 35).

The 15,000 South Moluccans who had emigrated to the Netherlands in 1951 after their republic had forcibly been incorporated by Indonesia, becoming the state of Negara Indonesia Timur, nursed similar grievances. Fed up with the lack of progress toward reestablishment of their national homeland, in June 1977 splinter elements of the Free South Moluccan Organization hijacked a Dutch passenger train and occupied a nearby schoolhouse. Hostages were taken in both incidents, but the terrorists were thwarted by Royal Dutch Marines, who managed to regain control of the train and the schoolhouse with minimal loss of innocent life (Hoffman 1998, p. 79).

The Irish Republican Army, already a half-century old, transformed itself into a terrorist organization in the late 1960s, initiating a time of "Troubles" for Ulster that was at its bloodiest during the five years spanning 1972 to 1976 . The IRA's body count declined significantly thereafter (Laqueur 1999, p. 33), but beginning in the latter part of that decade, the group's change of focus helped revive the "Golden Age of Assassination". IRA operatives assassinated the British ambassador to Ireland in 1976 and, three years later, murdered Lord Mountbatten, retired Viceroy of India and member of the royal family (ibid.; Rapoport 2004, p. 57). On 12 October 1984, avenging nine jailed terrorists who died as a result of a hunger strike protesting their treatment as ordinary criminals (Rapoport 2004, p. 57), an IRA bomb detonated at the Grand Hotel in Brighton narrowly missed killing Prime Minister Margaret Thatcher. Claiming 
responsibility for the failed assassination plot, the group released a letter driving home the fundamental asymmetry between terrorists and their high-profile targets: "Today, we were unlucky. But remember we have only to be lucky once. You will have to be lucky always" (quoted in Mickolus et al. 1989, vol. 2, p. 115).

The IRA was not the only group to resurrect the strategy of assassinating prominent political figures as the second post-1945 wave of terrorism washed its way around the globe. A year before Munich, Black September assassinated the Jordanian Prime Minister, and it killed the American ambassador to the Sudan in 1973 during an attack on the Saudi embassy compound in Khartoum. Spain's Prime Minister was murdered by the ETA, also in 1973. The next year, Black September tried to assassinate Jordan's King Hussein (Rapoport 2004, p. 57). ${ }^{14}$

\subsection{Lessons}

Although the second terrorist wave has been characterized here as primarily left-wing in origin, the three decades running from 1960 to the fall of the Berlin Wall in 1989 also were marked by the internationalization of terrorism. The PLO, as we have seen, played a major role in elevating terrorism to the global stage, not only as a result of the network of ideologically diverse terrorist groups it assembled in Europe and elsewhere by supplying training, money and weapons, but also by virtue of the terrorist acts carried out on its own account: the Palestinians "were more active in Europe than on the West Bank, and sometimes more active in Europe than many European groups themselves were" (Rapoport 2004, p. 58).

If the late nineteenth century was the "Golden Age of Assassination", the middle of the twentieth century's second half must have been the "Golden Age of Hijackings". Seven hundred of those incidents occurred during the ascendancy of the Palestinian-supported left-wing groups. Commercial aircraft were hijacked to gain media attention for terrorist causes, to secure hostages 
for use as bargaining chips in negotiating terrorist demands, and to tarnish the images of western governments. Other hostage events, such as the storming of the Nicaraguan Congress by the Sandinistas in 1978, the seizure of the Columbian Supreme Court by the terrorist group M-19 in 1985 (ibid., p. 57), and the South Moluccan occupation of a Dutch schoolhouse in 1977, had similar purposes and effects. Kidnappings, also rampant during the second wave, occurring in 73 countries, especially so in Italy, Spain and Latin America, usually were motivated by a more pedestrian consideration - ransom. It has been estimated that terrorists collected $\$ 350$ million dollars in the 409 international kidnapping incidents (yielding a total of 951 hostages) that took place between 1968 and 1982 (ibid.).

In contrast to the first post-1945 wave of anti-colonial terrorism, the left-wing terrorists of the second wave were by and large unsuccessful in achieving their goals. Their failures were due in part to an inability to articulate realistic objectives,${ }^{15}$ in part to the commission of acts, such as Aldo Moro's murder, that resulted in the loss of public support, and in part to the gradual undermining of their ideological foundations as the Soviet Union unraveled, and then finally collapsed. But left-wing terrorism also ebbed because of the effectiveness of countermeasures, including routine police work leading to the penetration of terrorist networks and the arrest of key terrorist leaders. ${ }^{16}$ Perhaps more significantly, embarrassed by the botched attempt to rescue the nine Israeli athletes taken hostage by Black September at the Munich Olympics, West Germany quickly moved to create the GSG-9 (Grenzschutzgruppe Neun), a special anti-terrorist unit of the national border police. France and Britain followed suit, establishing, respectively, the Groupe d'Intervention de la Gendarmerie Nationale (GIGN) and the Special Air Services (SAS) Regiment. These counterterrorism specialists carried out a number of successful operations over the next few years, for example, rescuing, in 1977, all 86 passengers on a Lufthansa flight 
hijacked to Mogadishu by a combined team of Palestinian and West German terrorists and, in 1980, saving 19 of the 21 hostages taken during a siege of the Iranian embassy in London, killing five of the six terrorists. ${ }^{17} \mathrm{Had}$ the United States done the same, the events shortly to play out at its embassy in Teheran might have ended differently (Hoffman 1998, pp. 72-73). ${ }^{18}$

\section{Islamist terrorism}

The Messenger of God said: "A martyr has six privileges with God. He is forgiven his sins on the shedding of the first drop of blood; he is shown his place in paradise; he is redeemed from the torments of the grave; he is made secure from the fear of hell and a crown of glory is placed on his head of which one ruby is worth more than the world and all that is in it; he will marry seventy-two of the huris with black eyes; and his intercession will be accepted for seventy of his kinsmen."

$$
\text { - Al-Khatib Al-Tibrizi, The Niches of Lamps }{ }^{19}
$$

It's a continuation of the Crusades. The crescent versus the cross. Comes down to that, wouldn't you say?

$$
\text { — Philip Caputo (2005, p. 25) }
$$

The third wave of "religious", primarily Islamist, terrorism emerged in the wake of the 1979 Iranian Revolution. It is still ongoing.

\subsection{Theological origins}

The genesis of what the American 9/11 Commission calls the "new terrorism" (National Commission on Terrorist Attacks upon the United States 2004, p. 47) are complex and less relevant here than their outward expression. One important element of the background story centers on a controversy that arose early in Islam's history over the proper line of succession to the Prophet Mohammed as Caliph, or leader of the Ummah, the community of Muslim faithful, a position combining both spiritual and temporal authority (Zakaria 2003, p. 147). Following the Prophet's death, successors at first were chosen from among his contemporaries, but as those too 
passed away, that method of selection was rendered impractical. One group, who became the Shi'a, argued that the Caliphate should remain in the hands of Mohammed's lineal descendants. Another group, who became the Sunni, contended that the Caliphate could be held by any man meeting certain standards of faith and learning. A series of bloody struggles led to Sunni ascendancy, a position it generally retains to this day. ${ }^{20}$

A second element involves the strand of fundamentalism woven into Islamic theology in the eighteenth century by Muhammad ibn Abd al-Wahhab (1703-1787), an Arabian cleric who fathered "a campaign of purification and renewal. His purpose was to return the Muslim world to the pure and authentic Islam of the Prophet, removing and, where necessary, destroying all later accretions" (Lewis 2001, p. 59). Wahhabism, and its own later accretions, represented in the writings of Sayyid Qutb, a member of the Muslim Brotherhood executed in 1996 on charges of treason against the Egyptian government (National Commission on Terrorist Attacks upon the United States 2004, p. 51), leads its adherents to disdain above all "false Muslims", imposters who have strayed from the true faith and, hence, merit treatment as kaffir (or kufr), unbelievers beyond the protection of the Ummah (Coll 2004, p. 203; Zakaria 2003, p. 125). Such sentiments motivated the assassination of President Anwar Sadat in 1981 by a group calling itself "The Islamic Group of Egypt", more popularly known as Al-Jihad, because of his failure to govern the country according to the Shar'ia (Rapoport 1990, pp. 104, 106). ${ }^{21}$

Contempt for the betrayers of Islam within their own ranks helps explain the late Yassir Arafat's uneasy relationship with Hamas, "a de facto branch of the Muslim Brotherhood" founded in December 1987 (Laqueur 1999, p. 138): his desire to establish an independent, secular Palestinian state made him vulnerable to being labeled un-Islamic. So, too, does scorn for false Muslims explain why many Islamist terrorists began their careers fighting their own 
governments: "The Arab rulers of the Middle East are autocratic, corrupt, and heavy-handed." But they are also "more liberal, tolerant, and pluralistic" than the true believers would prefer (Zakaria 2003, pp. 120, 125). Buying protection against accusations of betraying the true faith, "hoping to gain legitimacy by association" (ibid., p. 145), also may explain why the House of Saud openly embraces Wahhabism and generously funds fundamentalist religious schools (madrasas) and terrorist groups throughout the region. ${ }^{22}$ Last, fundamentalist hatred for the repressive, staunchly pro-American, insufficiently Muslim regime of Shah Mohammad Reza Pahlavi propelled the Ayatollah Khomeini from exile in Paris to Iran's highest office.

The Iranian Revolution of 1979 was wholly unexpected (Rapoport 2004, p. 62). Nor was the United States at all prepared for the revolutionaries' seizure of its embassy in Teheran, an event which plunged Jimmy Carter into a protracted hostage crisis that wrecked his presidency and catapulted Ronald Reagan into the White House. ${ }^{23}$ Ayatollah Khomeini's successful toppling of the Shah swept a Shi'a theocracy into power in Iran (National Commission on Terrorist Attacks upon the United States 2004, p. 52), subjecting the Iranians to a "dour, puritanical faith, policed by petty theocrats and religious commissars" (Zakaria 2003, p. 145). The Iranian Revolution also laid the foundations for the third post-1945 wave of terrorism. Khomeini's regime "inspired and assisted" Shi'a terrorist groups in Iraq, Saudi Arabia, Kuwait and Lebanon, most notoriously in the last of these where Hisballah (the "Party of God") soon came into existence (Rapoport 2004, p. 62). Terrorism had a new “able and active state sponsor", a role Iran played throughout the 1990s (Pillar 2001, p. 46). ${ }^{24}$

\subsection{Afghanistan and the collapse of the Soviet Union}

The foundations for the third wave of terrorism simultaneously were laid in Afghanistan, invaded by the Soviet Union the same year to put down a Muslim revolt against its puppet government in 
Kabul. The war against the mujaheddin was to last a decade, ending in 1989 with the withdrawal of Soviet troops bloodied by irregular "Arab Afghans" drawn from across the Sunni Ummah to participate "in what was the most important jihad of their lifetimes" (Pillar 2001, p. 46). The “freedom fighters" were subsidized generously both by Saudi Arabia and the United States. Conducting one of the Cold War's eleventh-hour conflicts by proxy, America supplied the mujaheddin with some $\$ 4$ to $\$ 5$ billion worth of modern weaponry (Rashid 2000, p. 18), including 900 Stinger missiles (ibid., p. 44), which it funneled covertly to them through Pakistan's Interservices Intelligence Directorate (ISID).

The Afghan war contributed to the rise of Islamist terrorism in several ways. First and foremost, "it provided terrorist-related skills and experience (in the use of firearms and explosives) to large numbers of non-Afghan militants" (Pillar 2001, p. 46). Secondly, it launched Osama bin Laden to prominence as a terrorist entrepreneur. Bin Laden, who for a time served as the main conduit of Saudi assistance to the mujaheddin (to which he added some of his own considerable wealth) and who brought his managerial skills to bear in helping to set up training camps for newly arrived fighters and to organize and strengthen Afghani resistance, established personal contact with many like-minded Muslims, making connections that would soon serve him well in creating the al-Qaeda terrorist network. Third, the flotsam of the Arab world who participated in the Afghan war drew from the Soviet Union's humiliation on the battlefield "the lesson that violence and Islam could defeat anyone", including the "Great Satan" left standing as the world's sole remaining superpower after 1989 (ibid.). Fourth, following the Soviet exit (and the collapse of their puppet regime in 1992), Afghanistan was left awash in money, guns and idle, battle-hardened Arab veterans, providing an immense stockpile of resources available for redeployment in support of Islamist terrorism wherever opportunity knocked. 
A final motivating force behind the third wave of terror, already underway at the start of the 1980 s, can be found in the collapse of the Soviet Union itself in the decade's final year, an event as stunning and as unanticipated as the Iranian Revolution had been. The end of Soviet hegemony in Eastern Europe and Central Asia opened the door to a host of ethnic or religiously based conflicts that had previously been repressed by authoritarian power. Although many of these conflicts have local causes, the terrorism that emerged in now-defunct Yugoslavia and in many of the former Soviet republics, including Azerbaijan, Chechnya, Georgia and Tajikistan, has transnational dimensions as well (ibid., p. 43). Moreover, other Muslim states formerly within the Soviet orbit, especially so Albania, have become safe havens for terrorist training and network-building (ibid. p. 44).

\subsection{Beirut and beyond}

Although most scholars trace the roots of the third post-1945 wave of terrorism to the events of 1979 in Teheran, the "new terrorism" also has an old friend, the Palestinian Liberation Organization. By the early 1980s, more than 40 different terrorist groups from around the world had received training in the PLO's camps in Jordan, Lebanon and Yemen (Hoffman 1998, p. 84). Reinforced by the Iranian-backed Hisballah, Lebanon, mired in civil war since 1975 (Laqueur 1999, p. 135), had become an important base of operations for terrorist attacks on neighboring Israel. Hisballah initially focused its terror on other, mainly Lebanese Christian targets, but it soon turned its attention south. As it had in 1978 (and as Syria had also done in 1976), Israel retaliated by invading Lebanon in 1982, abducting some of Hisballah's leaders and killing others. That invasion, which lasted three years, is credited by Walter Laqueur and other scholars with drawing the Lebanese Shi'a (and Iran) into the anti-Israel camp and contributing to the 
cycle of terrorist violence that continued well beyond the end of Lebanese civil war in 1989 (ibid.; Hoffman 1998, p. 97).

For the United States, the signal terrorist event at the start of the third wave was Hisballah's bombing of the Marine barracks in Beirut in 1983. More lives were lost in that incident (241) than the American armed forces sustained on any other single occasion during the two decades beginning in 1980 (Pillar 2001, p. 20). Combined with its other actions, taking western hostages, murdering US and French soldiers, attacking a French military base and, in April 1983, bombing the Beirut embassies of both nations, Hisballah succeeded in forcing the multinational peacekeepers to pull out of Lebanon in early 1984 (ibid., pp. 36-37; Laqueur 1999, p. 137).

All told, there were 5431 transnational terrorist incidents during the 1980s, claiming 4684 lives (Pillar 2001, p. 42). Partly as a consequence of the Soviet Union's collapse which, along with the inward turning of ethnic conflict, contributed to the precipitous decline of left-wing terrorism already underway as a result of effective police work by shutting off an important source of external support for those groups, the 1990s witnessed far fewer terrorist events. The figures for the last decade of the twentieth century were 3824 incidents and 2468 fatalities (ibid.). ${ }^{25}$

While the number of terrorist incidents has been falling over the past 20 years, terrorism has become increasingly lethal. There were $19 \%$ fewer events in the second half of the 1990 s, compared with the first half, but deaths more than doubled. The new, largely Islamist terrorism has been designed to inflict high casualties (ibid.; Enders and Sandler 2000). Islamist terrorism also is distinguished by its indifference to "collateral damage": bin Laden himself has said that, "We do not have to differentiate between military or civilian. As far as we are concerned, they 
are all targets" (National Commission on Terrorist Attacks upon the United States 2004, p. 47). Terrorism is not just theater any longer. ${ }^{26}$

A small sample of the terrorist events that rounded out the twentieth century includes the following. $^{27}$

- The hijacking by Lebanese Shi'a terrorists, on 14 June 1985, of TWA Flight 847 while en route from Rome to Cairo.

- In 1986, the explosion of a bomb at a Berlin disco, killing two American soldiers.

- The destruction, by bomb, of Pan Am Flight 103 over Lockerbie, Scotland, in December 1988, killing all 259 passengers and crew, plus 11 people on the ground at the crash site.

- The bombing, in December 1992, of two hotels in Aden where US troops routinely stopped while awaiting deployment to units in Somalia, killing two persons, but no Americans.

- The murder of two CIA agents by Mir Amal Kansi, a Pakistani Islamic extremist, at the main entrance to the CIA's headquarters in Langley, Virginia, on 25 January 1993.

- The bombing of New York City's World Trade Center on 26 February 1993, killing six and injuring more than 1000.

- A series of 13 nearly simultaneous car and truck bombs detonated in Bombay, India, in February 1993, in reprisal for the destruction of a Muslim shrine, killing 400 and injuring 1000 others.

- The February 1994 massacre, by Baruch Goldstein, of 29 Palestinians in a Hebron mosque. 
- The release of sarin nerve gas into a Tokyo subway by Aum Shinrikyo in March 1995, killing 12 and injuring thousands.

- The bombing of the Alfred P. Murrah Federal Building in Oklahoma City on 13 April 1995, killing 168.

- The attempted assassination, in June 1995, of Egyptian President Hosni Mubarak during a visit to Ethiopia.

- The October 1995 assassination, in Malta, of Fathi Shiqaqi, principal leader of the Palestine Islamic Jihad, by Israeli operatives.

- The explosion of a car bomb, in November 1995, outside a joint Saudi-US training facility for the Saudi National Guard in Riyadh, killing five Americans and two Indian officials.

- The assassination of Israeli Prime Minister Yitzhak Rabin in November 1995 by a Jewish extremist, intended to disrupt the peace process.

- A series of strikes by Hamas suicide bombers during February and March 1996, intended to disrupt Israel's national elections, killing 60 altogether.

- In April 1996, an attack, using machine guns and hand grenades, on a group of western tourists outside their Cairo hotel, killing 18.

- The truck bomb detonated, in June 1996, in the Khobar Towers, a residential complex in Dhahran, Saudi Arabia, housing US Air Force personnel, killing 19 Americans and wounding 372.

- The massacre, in November 1997, of 58 foreign tourists and four Egyptians at the Temple of Queen Hatshepsut in Luxor. 
- The coordinated bombings, on the morning of 7 August 1998, of the US embassies in Nairobi, Kenya - killing 12 Americans and 201 others (mostly Kenyans) and injuring 5000 - and Dar es Salaam, Tanzania, killing another 11, but no Americans.

- On 3 January 2000, the attempted bombing of the USS The Sullivans in the port of Aden.

- The bombing of the USS Cole on 12 October 2000, again in Aden, killing 17 and wounding at least 40 .

The last decade of the twentieth century also brought terror back to Algeria. Spurred by an Islamic revival that began there in the late 1970s, the Muslim political party FIS (Islamic Salvation Front) won impressive victories in the 1991 national elections. The ruling government, whose political base rested on the more secular Algerian middle class, responded to electoral defeat by nullifying the results, declaring a state of emergency and banning its Islamic opposition. Civil war soon erupted. The Muslim side of that war has been dominated by the brutal GIA (Armed Islamic Group), whose core consists of a hundred or so veterans of Afghanistan. Partial to cutting the throats of its victims, the GIA has killed indiscriminately, targeting teachers, journalists and government workers, including letter carriers and street sweepers. It set a deadline of 1 January 1994 for all foreign nationals to leave the country and, over the next two years, slaughtered about one hundred of those who did not heed its warning, among which were 12 Croat technicians, a French bishop, and a number of priests, nuns and pensioners. The GIA carried its terror to metropolitan France in 1995, killing eight civilians in the Paris metro and other public places (Laqueur 1999, pp. 130-133); more than 180 others were wounded during that bombing campaign, which ran from July to October. By century's end, as 
many as 100,000 people are thought to have perished in the Algerian bloodbath that began in 1992 and is still underway (Pillar 2001, p. 19).

\section{The constitutional perspective}

The advantages of possessing the control of the powers of the government, and thereby of its honors and emoluments, are, of themselves, exclusive of all other considerations, ample to divide ... a community into two great hostile parties.

- John C. Calhoun ${ }^{28}$

I created Transjordan with the stroke of a pen on a Sunday afternoon in Cairo. - Winston S. Churchill ${ }^{29}$

Just as there is no unique terrorist personality, there can be no single cause of terrorism. The possible explanations for terrorism are as many and varied as are the differences between Christian and Muslim, Jew and Arab, Catholic and Anglican, Shi'a and Sunni, Kurd and Turk, or Andreas Baader and Timothy McVeigh. But in the long and bloody history of terrorism, at least as it has evolved since the end of the Second World War, there is one common thread. If that thread is traced backwards in time, it ends in the events of 1914-1922, when the modern map of the Middle East and Central Asia was being drawn.

No one then living within the boundaries of wrecked Ottoman suzerainty or in the colonies of the defeated German and Austro-Hungarian empires was present when decisions were being taken about the area's future geopolitical landscape: "Europeans and Americans were the only ones seated around the table ..." (Fromkin 1989, p. 17). As a result of the victorious powers' ignorance of the ground, the pressure of time, a hunger for vengeance, an inclination to maintain and even to expand colonial spheres of influence, and, without doubt, countless other factors, new national frontiers were fabricated with little regard for customary tribal and ethnic territorial claims or existing trade patterns and social networks. In consequence, the map that 
emerged from the Paris Peace Conference and from the events that followed over the next few years was by and large imposed arbitrarily by outsiders, introducing "an artificial state system into the Middle East [the Balkans, Central Asia and beyond] that has made it into a region of countries that have not yet become nations even today" (ibid.)

\subsection{Afghanistan}

Afghanistan exemplifies. Its southern border was first drawn in the late nineteenth century by Sir Mortimer Durand, the colonial government of India's foreign secretary, expressly to divide the Pashtun tribe's homeland in half, thereby creating a buffer zone against Russian expansionism on India's northwest frontier. When the Pashtunis who found themselves on the Indian side of the Durand line failed to integrate themselves peaceably under the Raj, the North-West Frontier Province was sliced off from the Punjab to create a second, inner buffer. These two "tribal belts" were incorporated formally within the boundaries of Pakistan when that nation separated from newly independent India under the Partition Plan effective 14 August 1947 (Hilton 2001).

Afghanistan's northern border was drawn by Josef Stalin. Formalized in the so-called Settlement of 1922, a series of treaties between the Soviet Union and a number of its neighbors, including Turkey and Persia (Fromkin 1989, p. 559), carved up a region, "comprising modern day Tajikistan, southern Uzbekistan, and northern Afghanistan", that had been "one contiguous territory for centuries" (Rashid 2001, p. 146). ${ }^{30}$ Like Sir Mortimer Durand before him, Stalin apparently intended to create his own buffer zone against the Pashtuns (and the Raj) by stranding sizeable Tajik and Uzbek populations in territory that thenceforth became part of Afghanistan.

\subsection{The Middle East}


Much the same forces shaped frontiers in the Middle East: "Iraq and what we now call Jordan, for example, were British inventions, lines drawn on an empty map ...” (Fromkin 1989, p. 17), as Winston Churchill's boast adopted as an epigraph above so well illustrates. Similarly, "the boundaries of Saudi Arabia [and] Kuwait ... were established by a British civil servant in 1922, and the frontiers between Muslims and Christians were drawn by France in Syria-Lebanon and by Russia on the borders of Armenia and Soviet Azerbaijan" (ibid.). The sequel to the First World War is as significant for what it did not do, as it is for what it did do. On the agenda for settlement in 1921, the issue of independence or autonomy for the Kurds "somehow disappeared from the agenda in 1922”; Kurdistan was not to be (ibid., p. 560). As a result of that nondecision, the Kurds, mostly Sunni Muslims thought to be of Indo-European descent, now inhabit the mountainous region straddling the borders of Iraq, Iran, Russian Armenia and Turkey (ibid., p. 503). ${ }^{31}$

The foundations for much of the terrorism of the twentieth century (and certainly that of both the first and third post-1945 terrorist waves) thus were laid in 1914-1922. (To the extent that the left-wing terrorist groups declared common cause with - and received substantial support from - the oppressed peoples of the Third World, the Palestinians in particular, so too were the second wave's foundations.) Churchill's haphazard decision separating Transjordan “a disordered area of tribal conflict" (ibid., p. 442) - from the balance of Britain's Palestine Mandate echoes down to this day: ${ }^{32}$ the view still persists in Israel, especially so in the ranks of the Herut Party, that "Jordan either is or should be an Arab Palestinian state" (ibid., p. 528). The colonial attitudes informing the policies adopted by Britain and France in exercising the mandatory powers granted to them by the League of Nations also contributed to the rise of modern terrorism. For their part, the British attempted to displace "the basis of political life in 
the Middle East - religion - [with] nationalism or dynastic loyalty" (ibid., p. 17). On the other hand, "the French government, which in the Middle East did allow religion to be the basis of politics - even of its own - championed one sect [the Christians] against the others ...”, thereby helping foster the civil strife that has ravaged Lebanon ever since (ibid., p. 17; emphasis in original).

And then there is Iraq, where, in 1922, "Kurdish, Sunni, Shi'ite, and Jewish populations had been combined into a new ... country ... under the rule of an Arabian prince ..." (ibid., p. 528). Britain, in the person of Gertrude Bell, had already been put on notice by an American missionary that attempting to unite the Mesopotamian provinces was an impractical goal:

You are flying in the face of four millenniums of history if you try to draw a line around Iraq and call it a political entity! Assyria always looked to the west and east and north, and Babylonia to the south. They have never been an independent unit. You've got to take time to get them integrated, it must be done gradually. They have no conception of nationhood yet. (ibid., p. 451)

In the event, after drawing a line around Iraq and calling it a political entity, Britain proceeded to fumble its mandate. Opposition to British military rule arose almost immediately. Large-scale protest demonstrations during 1919 grew, by June 1920, into open revolt in the Sunni center of the new state, the Shi'a south and the Kurdish north. The British responded with armed force, eventually quelling the revolt the following month, at the cost of 500 deaths among the British and Indian Army garrison and 6000 Iraqi lives. The brunt of the British counterstrike was borne by the Shi'a, heightening their disaffection from their Sunni Muslim brothers (Keegan 2004, pp. 14-15).

Britain sought to redress the grievances that led to revolt by appointing a council of Iraqi ministers through which to rule indirectly, in the hope that the council would be more acceptable to the general population than direct military administration. "Perhaps inevitably, however, a 
majority of the appointees were ... chosen from the Sunni minority, since they were identified by the British as more dependable and experienced than Shi'a or Kurds. Sunni domination was particularly evident in the new Iraqi army ..." (ibid., p. 15). Hard feelings were inflamed further. So were they by Britain's selection of a Sunni prince, Amir Faisal, to serve as the sovereign of the embryonic Iraqi state (ibid., p. 17). Hence, it is to the artificial national ground prepared by the British under their mandate that we owe the hostilities evident in post-Saddam Iraq, between Sunni and Shi'a and between Muslims and Kurds, both of which are overlaid by Turkey's territorial ambitions in that country's northern oil-bearing provinces.

\subsection{Lessons}

The geopolitical decisions taken in the aftermath of the First World War have had disastrous consequences for the Middle East and for Central Asia, as similarly arbitrary mapmaking also had for sub-Saharan Africa (Rowley 1999). Members of some close-knit ethnic groups suddenly found themselves on opposite sides of new, unasked-for national borders; others were compelled to share ground with their enemies of old. Ethnic violence and tribal warfare were the predictable outcomes of that unhappy state of affairs as rival groups contested for control of the levers of local, regional or national political power. Autocrats, who "placed their highest priority on preserving the elite's grip on national wealth" (National Commission on Terrorist Attacks upon the United States 2004, p. 53), would rise and fall as their supporting coalitions gained the upper hand - only to be displaced by some other strongman. Political authority would be exercised not by sharing power with other groups, but by repressing them.

Short of wholesale reconfiguration of the maps of the Middle East and Central Asia, as has been proposed for sub-Saharan Africa (Kimenyi 1999), liberal constitutions offer a republican cure for the factional diseases plaguing the failed states that were created in 1914 
1922 and have been the incubators of post-1945 terrorist activity. Federal systems of government that shift most political decision-making authority away from the center toward regions having a high degree of local autonomy, combined with a representative legislature empowered to resolve tightly defined questions of national policy, are time-tested ways of accommodating the diverse interests of an ethnically or religiously heterogeneous polity (Frey and Eichenberger 1999). ${ }^{33}$

The writing and ratification of liberal constitutions establishing the rule of law, securing private property rights and civil liberties, and, above all, limiting governmental powers, require a society's politically effective groups to coordinate on a particular political (and sometimes economic) order, to those groups' mutual advantage (Hardin 1999, pp. vii-viii). It is an open question whether such coordination is possible in Afghanistan, Iraq and many of the other pseudo states in that part of the world where terrorism has raised its ugly head. What is clear, however, is that for democratic reforms to have a chance, constitutionalism must precede popular voting. "Elections alone do not produce democracy" (Zakaria 2003, p. 259) and, in fact, if voting comes before the establishment of liberal political institutions - the very reason for having a constitution in the first place - one risks domination of the constitution-writing stage by the very same well-organized factions that controlled power in the preceding autocratic regime. Russia, whose popularly elected president, Vladimir Putin, rules autocratically, supplies a cautionary tale.

Those who are impatient for democracy in the Middle East and Central Asia as well as doubtful that new constitutions and, perhaps, new political maps are required to mitigate the root causes of terrorism should remember that "it took Europe a millennium and a half to resolve its post-Roman crisis of social and political identity: nearly a thousand years to settle on the nationstate form of political organization, and nearly five hundred years more to determine which 
nations were entitled to be states" (Fromkin 1989, p. 565). Indeed, "it was only at the end of the nineteenth century, with the creation of Germany and Italy, that an accepted map of western Europe finally emerged, some 1,500 years after the old Roman map started to become obsolete" (ibid.). It may well take another millennium and a half before the centrifugal forces set in motion by the Soviet Union's collapse, the defeat of the Taliban and the toppling of Saddam Hussein coalesce into some semblance of sustainable geopolitical order.

\section{Concluding remarks}

This paper has traced the history of modern terrorism from the end of the Second World War to the beginning of the twenty-first century. It divided that history into three stylized waves: terrorism in the service of national liberation and ethnic separatism, left-wing terrorism, and Islamist terrorism. Adopting a constitutional political economy perspective, the paper argued that the terrorism of 1945-2000 is largely, but certainly not exclusively, rooted in the artificial nation-states fashioned by the First World War's victors from the carcass of the Ottoman Empire, reinforced by the unkept promises of self-determination made in turn by Woodrow Wilson and the signatories to the Atlantic Charter. Largely suppressed, during the interwar period, by the colonial powers, and from 1945 until 1989 by Soviet hegemony, the centrifugal forces of ethnic and national identity boiled over by the twentieth century's end. Those forces have been magnified since 1979 by the rise of a new, virulent Islamist terrorism. The religious overtones of that movement should not be allowed to obscure terrorism's predominant common origins - including that of the European leftists, who would not have survived nearly as long without the support of the Palestinians - in the failed states created in 1914-1922. 
The history of terrorism in the second half of the twentieth century would have been quite different had Transjordan, as it was intended to be, been made a Palestinian homeland; if Kurdistan had not been mysteriously overlooked in the Settlement of 1922; if a line had not been drawn around Iraq, but that Mesopotamia had instead been divided along its three natural internal boundaries; and if Armenians, Tajiks, Uzbeks, Pashtuns, Punjabis and many other ethnic populations had not been marooned across the borders of two or more contrived nation-states. Alternatively, imagine that, instead of rewarding Arab chieftains with monarchial powers, elevating Sunni over Shi'a or Muslim over Christian, Britain and France had imposed federalist constitutions, providing for weak central governments, substantial local or regional autonomy, and a recognized right of secession, on the nations of the Middle East as then (and now) configured. What might have been?

It is somewhat ironic that, at the same time nationalism and ethnic separatism are on the rise in the Middle East and Central Asia, accompanied by the terrorism that has been their historical handmaiden, Europe itself is moving in the opposite direction, toward centralization of governmental authority in Brussels. In order to implement fuller political and economic union on the Continent, a new European constitution was written and submitted for ratification by the Union's member states. The decisive rejection of that document by voters in France and the Netherlands in the spring of 2005 proved that, for very different reasons, national sovereignty is not to be sold cheaply by Europe's political elites. Constitutional design evidently still matters. It, not democracy, also ought to be Europe's (and America's) top priority for dealing with the threat of modern terrorism.

\section{Acknowledgements}


I thank Michael Reksulak and Hilary Shughart for detailed comments on an earlier version of the paper. Charles Rowley, Gordon Tullock, Ronald Wintrobe and other participants in the Conference on the Political Economy of Terrorism held at George Mason University Law School on 24-25 May 2005 helped improve the paper considerably. So, too, did Todd Sandler, who generously read the penultimate draft and provided a number of very helpful suggestions. All of these friendly critics are hereby held harmless for the final product. The financial support of the Critical Infrastructure Protection Program and the James M. Buchanan Center for Political Economy is gratefully acknowledged.

\section{Notes}

1. Quoted in Coll (2004, p. 139).

2. The last two distinguishing characteristics of modern terrorism are exemplified in the proclamation of the Front de Libération Nationale (F.L.N.), issued on the eve of the launching of full-scale Muslim revolt against French colonialism in 1954, nearly a decade after V.E. Day's events at Sétif. The F.L.N. announced that it would use "every means" necessary to realize its goal of Algerian independence, including "action abroad to make the Algerian problem a reality for the entire world" (Horne 1977, p. 95).

3. Terrorists, as we shall see later, sometimes have no clearly articulated goals. The lack of well-defined objectives played an important role in ending of the wave of left-wing terror that plagued Europe during the second half of the twentieth century.

4. A terrorist act carrying with it certain death may not be irrational at all in an evolutionary perspective: "the minimum requirement for a suicidal altruistic gene to be successful is that it should save more than two siblings (or children or parents), or more than four half- 
siblings (or uncles, aunts, nephews, nieces, grandparents, grandchildren), or more than eight first cousins, etc. Such a gene, on average, tends to live on in the bodies of enough individuals saved by the altruist to compensate for the death of the altruist itself" (Dawkins [1976] 1989, p. 93).

5. See Reich (1990) and Turk (2004) for additional analyses in the psycho-social tradition.

6. A more formal exposition of these ideas, applying rational-choice thinking to revolutions and coups d'état, is contained in Tullock (1974).

7. The IRA, "for example, ... cleverly changed its methods for detonating bombs, using devices ranging from radar guns to photographic flash equipment, to stay ahead of the British use of electronic measures to prevent detonations" (Pillar 2001, p. 39).

8. In contrast, Landes (1978) found that, owing to their anonymity, the placing of federal sky marshals on commercial aircraft did not significantly deter terrorist hijackings. More recent tests of the effectiveness of sky marshals have likewise produced insignificant results, perhaps because their deterrent effects, if any, cannot be disentangled empirically from the many other security upgrades implemented in the wake of 9/11.

9. Although "terrorist" may have been coined by Burke, Thomas Hobbes used its root more than a century earlier. Because Hobbes did not think that a mutually agreed to covenant elevating humankind from the state of nature would be self-enforcing, "there be somwhat else required", namely, "a Common Power, to keep them in awe, and to direct their actions to a Common Benefit." Moreover,

the only way to erect such a Common Power ... is, to conferre all their power and strength upon one Man, or upon one Assembly of men, that may reduce all their Wills, by plurality of voices, unto one Will.... This is the generation of that great LEVIATHAN ... to which wee owe ... our peace and defense. For by this Authoritie, given him by every particular man in the Common-Wealth, he hath the use of so much Power and Strength 
conferred on him, that by terror thereof, he is able to conforme the wills of them all, to Peace at home, and mutuall ayd against their enemies abroad. (Hobbes ([1651] 1996, pp. 120-121; emphasis added)

10. As the EOKA's military leader, George Grivas, concluded in hindsight, the British commander "underrated his enemy on the one hand, and overweighted his forces on the other. But one does not use a tank to catch field mice - a cat will do the job better" (Hoffman 1998, p. 59).

11. Warnings to evacuate the hotel were issued (Hoffman 1998, p. 51) in what apparently was Irgun's common practice (Rapoport 2004, p. 55).

12. Meinhof hanged herself in 1976; Baader committed suicide the following year (Merari 1990, p. 196).

13. Black September, eight strong on the morning of 5 September 1972, killed two of the Israeli athletes immediately and took nine others hostage. The group offered to exchange its hostages for 236 Palestinians imprisoned in Israel and five other terrorists being held in West German jails, among which were Andreas Baader and Ulrike Meinhof, plus a guarantee of safe passage to an Arab country. After a deal was struck, the terrorists and their hostages were transported on two helicopters to a Lufthansa Boeing 747 waiting at a nearby military airbase. Expecting to be flown to Cairo, which initially had agreed to serve as the site for the hostage exchange but subsequently decided to refuse landing rights, the helicopters were instead met by a prearranged rescue operation, including a contingent of five West German police sharpshooters. One German policeman and all but three of the Black September terrorists were killed in the ensuing firefight. So, too, were all nine Israeli hostages, apparently the victims of a hand grenade tossed by a terrorist into one of the helicopter's cabins (Hoffman 1998, pp. 71-72). 
14. King Hussein and the Prime Minister murdered in 1971 both were targeted for assassination by Palestinian terrorists in retaliation for their nation's expulsion of the PLO in 1970, following that group's hijacking of British and American commercial aircraft to Jordan (Rapoport 2004, pp. 57, 59).

15. "They are bent on the destruction of the current Western system, ... but they are not really interested in what should come after that destruction" (Kellen 1990, p. 55). Like the Russian nihilists of the previous century, the New Left terrorists wanted to wreck the "system", but had no practical plans for replacing it, other than with "universally allhuman social republic and harmony" (Dostoevsky [1872] 1994, p. 53). Living in a "fantasy world" (Laqueur 1999, p. 28), "they got everything out of books, and even at the first rumor from our progressive corners in the capital were prepared to throw anything whatsoever out the window, provided they were advised to throw it out" (Dostoevsky [1872] 1994, p. 31). As Russell Hardin (1995, p. 41) observes, “Coordination without clear enough purpose will soon collapse.”

16. According to Walter Laqueur (1999, p. 45), "the only effective weapon against terrorism in the modern era has been the infiltration of their ranks and the use of informers." Paul Pillar agrees, emphasizing the importance to counterterrorism efforts of "cell-by-cell, terrorist-by-terrorist disruption of terrorist infrastructures, mainly accomplished through raids, arrests, interrogations, and other measures by ... police and security services ..." (Pillar 2001, p. xli). If the top leaders of terrorist groups, like dictators, have incentives to hold on to their positions of power by weakening or eliminating potential rivals (Tullock 1974, pp. 72-73), then capturing or killing high-profile terrorist kingpins, such as Osama 
bin Laden, promises to advance the war on terror considerably insofar as their successors will tend to be less able.

17. Already having established such a force, Israeli commandos stormed the Air France aircraft hijacked to Entebbe in June 1976, killing all of the terrorists and rescuing all but one of the 105 hostages (National Commission on Terrorist Attacks upon the United States 2004, p. 96).

18. America's Delta Force was not created until the late 1970s. Its first test, during the Iranian hostage crisis in April 1980, was the disastrous "Desert One" operation, in which five airmen and three marines perished (National Commission on Terrorist Attacks upon the United States 2004, p. 96).

19. Quoted in Rapoport (1990, pp. 117-118).

20. Iran often is identified as the only nation within the modern Middle East where Shi'a comprise the majority (National Commission on Terrorist Attacks upon the United States 2004, p. 50; Keegan 2004, p. 43), but 60\% of Iraq's 25 million souls are Shi'a (Zakaria 2003, p. 261). Iran, to be sure, was the only Muslim nation where Shi'a dominated the institutions of government prior to Saddam Hussein's overthrow by “Operation Iraqi Freedom".

21. Assassination is far from new in the Muslim world. Some $35 \%$ to $40 \%$ of the caliphs following in the Prophet's footsteps met that fate (Rapoport 1990, p. 125). Indeed, the word itself originated in the name given to a Shi'a Muslim sect of "hashish eaters" (“assassins") that operated against the Crusaders in present-day Syria and Iran between 1090 and 1272 (Hoffman 1998, p. 89; Laqueur 1999, p. 11). The Caliphate was 
extinguished in 1925 at the behest of Turkey's secular ruler, Mustapha Kemal Atatürk (Keegan 2004, p. 91).

22. Owing to its cooperation with the international coalition assembled by President George H. W. Bush during the Gulf War, allowing US troops to be stationed on Saudi soil in 1991 - and reacting perhaps even more strongly to Saudi attempts to silence him that same year (National Commission on Terrorist Attacks upon the United States 2004, p. 57) - Osama bin Laden already has called for taking up arms against the Saudi government. In his 1996 declaration of jihad, bin Laden pronounced that King Fahd's "regime betrayed the ummah and joined the kufr, assisting and helping them against the Muslims" (Zakaria 2003, p. 125).

23. Fifty-three Americans were held hostage. That event, the 9/11 Commission observed laconically, “ended the State Department's leadership in counterterrorism” (National Commission on Terrorist Attacks upon the United States 2004, p. 94).

24. Enders and Sandler (2000) report very strong statistical support for the conjecture that the third terrorist wave began in 1979. They also find that terrorist incidents have on average become more bloody since then.

25. In addition, more than 31,000 people sustained non-fatal injuries as a result of transnational terrorist incidents over the last two decades of the twentieth century (Pillar 2001, p. 19).

26. During the $1990 \mathrm{~s}$, less than $0.01 \%$ of the terrorist attacks caused $70 \%$ of the terrorismrelated injuries and 19\% of the deaths (Johnson 2001, p. 905).

27. The sources for the list are Hardin (1995, p. 216), Hoffman (1998, pp. 18, 92-93, 132), Pillar (2001, p. 121) and National Commission on Terrorist Attacks upon the United 
States (2004, pp. 59, 60, 62, 70, 71, 98, 100, 180, and 190). For additional examples, see US Department of State, "Significant Terrorist Incidents, 1961-2003: A Brief Chronology", accessible at http://www.state.gov/r/pa/ho/pubs/fs/5902pf.htm.

28. Quoted in Hardin (1999, p. 276).

29. Quoted in Collins and Lapierre (1972, p. 83).

30. Turkestan already had been carved out of the previously independent Muslim Central Asian world by the czars (Fromkin 1989, p. 477).

31. Other border questions remained unresolved: “Turkey's frontier with Syria, for example, was established only at the end of the 1930s" (Fromkin 1989, p. 559).

32. C. D. Brunton, a British officer serving in Transjordan wrote presciently that "the people here do not form a homogeneous political entity... You cannot expect them to form a government for their common country" (Fromkin 1989, p. 443).

33. Frey (2004, pp. 85-92) recently has extolled the virtues of "polycentricity" as a way of reducing a nation's vulnerability to terrorist attacks. A polycentric political system would, in my view, make terrorism less likely in the first place.

\section{References}

Alexander, Y. \& Pluchinsky, D. (1992). Europe's Red Terrorists: The Fighting Communist Organizations. Frank Cass: London.

Barry, J. M. (2004). The Great Influenza: The Epic Story of the Deadliest Plague in History. Penguin Books: New York and London.

Caputo, P. (2005). Acts of Faith. Knopf: New York. 
Coll, S. (2004). Ghost Wars: The Secret History of the CIA, Afghanistan, and bin Laden, from the Soviet Invasion to September 10, 2001. Penguin: New York.

Collins, L. \& Lapierre, D. (1972). O Jerusalem! Simon \& Schuster: New York.

Cooper, H. H. A. (2001). Terrorism: The Problem of Definition Revisited. American Behavioral Scientist 44(6): 881-893.

Crenshaw, M. (1990). The Logic of Terrorism: Terrorist Behavior as a Product of Strategic Choice. In Reich, W. (ed.) Origins of Terrorism: Psychologies, Ideologies, Theologies, States of Mind, 7-24. Woodrow Wilson Center: Washington, DC, and Johns Hopkins University Press: Baltimore and London.

Dawkins, R. ([1976] 1989). The Selfish Gene. Oxford University Press: Oxford and New York. Dostoevsky, F. ([1872] 1994). Demons: A Novel in Three Parts. Pevear, R. \& Volokhonsky, L. (trans.) Knopf: New York.

Enders, W. \& Sandler, T. (1993). The Effectiveness of Antiterrorism Policies: A VectorAutoregression-Intervention Analysis. American Political Science Review 87(4): 829_ 844.

Enders, W. \& Sandler, T. (1995). Terrorism: Theory and Applications. In Hartley, K. \& Sandler, T. (eds.) Handbook of Defense Economics, vol. 1, 213-49. North-Holland: Amsterdam.

Enders, W. \& Sandler, T. (2000). Is Transnational Terrorism Becoming More Threatening? A Time-Series Investigation”. Journal of Conflict Resolution 44(3): 307-332.

Enders, W. \& Sandler, T. (2004). What Do We Know about the Substitution Effect in Transnational Terrorism? In Silke, A. \& Ilardi, G. (eds.) Researching Terrorism: Trends, Achievements, Failures, 119-137. Frank Cass: Ilford.

Enders, W., Sandler, T. \& Cauley, J. (1990). UN Conventions, Technology, and Retaliation in 
the Fight against Terrorism: An Economic Evaluation. Terrorism and Political Violence 2(1): 83-105.

Ferracuti, F. (1990). Ideology and Repentance: Terrorism in Italy. In Reich, W. (ed.) Origins of Terrorism: Psychologies, Ideologies, Theologies, States of Mind, 59-64. Woodrow Wilson Center: Washington, DC, and Johns Hopkins University Press: Baltimore and London.

Frey, B. S. (2004). Dealing with Terrorism - Stick or Carrot? Edward Elgar: Cheltenham, UK and Northampton, MA, USA.

Frey, B. S. \& Eichenberger, R. (1999). A New Proposal for Federalism and Democracy in Developing Countries. In Kimenyi, M. S. \& Mbaku, J. M. (eds.) Institutions and Collective Choice in Developing Countries: Applications of the Theory of Public Choice, 315-326. Ashgate: Aldershot, UK and Brookfield, VT, USA.

Fromkin, D. (1989). A Peace to End all Peace: The Fall of the Ottoman Empire and the Creation of the Modern Middle East. Henry Holt: New York.

Gurr, T. R. (1990). Terrorism in Democracies: Its Social and Political Bases. In Reich, W. (ed.) Origins of Terrorism: Psychologies, Ideologies, Theologies, States of Mind, 86-102. Woodrow Wilson Center: Washington, DC, and Johns Hopkins University Press: Baltimore and London.

Hardin, R. (1995). One for All: The Logic of Group Conflict. Princeton University Press: Princeton, NJ.

Hardin, R. (1999). Liberalism, Constitutionalism, and Democracy. Oxford University Press: Oxford and New York.

Heinlein, R. A. ([1966] 1994). The Moon is a Harsh Mistress. Tom Doherty: New York. 
Hilton, I. (2001). The Pashtun Code. New Yorker 77(38): 58-71.

Hirshleifer, J. (1991). The Paradox of Power. Economics and Politics 3(3): 177-200.

Hobbes, T. ([1651] 1996). Leviathan. Revised Student Edition, ed. by Tuck, R. Cambridge Texts in the History of Political Thought. Cambridge University Press: Cambridge.

Hoffman, B. (1998). Inside Terrorism. Columbia University Press: New York.

Horne, A. (1977). A Savage War of Peace: Algeria 1954-1962. Viking Press: New York.

Johnson, L. C. (2001). The Future of Terrorism. American Behavioral Scientist 44(6): 894-913.

Keegan, J. (2004). The Iraq War. Knopf: New York.

Kellen, K. (1990). Ideology and Rebellion: Terrorism in West Germany. In Reich, W. (ed.)

Origins of Terrorism: Psychologies, Ideologies, Theologies, States of Mind, 43-58.

Woodrow Wilson Center: Washington, DC, and Johns Hopkins University Press:

Baltimore and London.

Kimenyi, M. S. (1999). Spatial Competition, Ethnicity, and the Optimal Size and Composition of Units of Collective Choice. In Kimenyi, M. S. \& Mbaku, J. M. (eds.) Institutions and Collective Choice in Developing Countries: Applications of the Theory of Public Choice, 355-380. Ashgate: Aldershot, UK and Brookfield, VT, USA.

Landes, W. M. (1978). “An Economic Study of U.S. Aircraft Hijackings, 1961-1976”. Journal of Law and Economics 21(1): 1-31.

Laqueur, W. (1999). The New Terrorism: Fanaticism and the Arms of Mass Destruction. Oxford University Press: Oxford and New York.

Levitt, S. D. \& Dubner, S. J. (2005). Freakonomics: A Rogue Economist Explores the Hidden Side of Everything. William Morris (HarperCollins): New York.

Lewis, B. (2001). The Revolt of Islam. New Yorker 77(36): 50-63. 
Liddell Hart, B. H. ([1971] 1999). History of the Second World War. Da Capo Press: New York. Macmillan, M. (2002). Paris 1919: Six Months that Changed the World. Random House: New York.

Merari, A. (1990). The Readiness to Kill and Die: Suicidal Terrorism in the Middle East. In Reich, W. (ed.) Origins of Terrorism: Psychologies, Ideologies, Theologies, States of Mind, 192-207. Woodrow Wilson Center: Washington, DC, and Johns Hopkins University Press: Baltimore and London.

Mickolus, E. F., Sandler, T. \& Murdock, J. M. (1989). International Terrorism in the 1980s: A Chronology of Events, 2 vols. Iowa State University Press: Ames.

National Commission on Terrorist Attacks upon the United States. (2004). The 9/11 Commission Report: Final Report of the National Commission on Terrorist Attacks Upon the United States. Norton: New York and London.

Office of the Coordinator of Counterterrorism (1997). Patterns of Global Terrorism, 1986. US Department of State Publication 10433. US Department of State: Washington, DC.

Olson, M. (1965). The Logic of Collective Action: Public Goods and the Theory of Groups. Harvard University Press: Cambridge, MA.

Pillar, P. R. (2001). Terrorism and U.S. Foreign Policy. Brookings Institution: Washington, DC.

Post, J. M. (1990). Terrorist Psycho-Logic: Terrorist Behavior as a Product of Psychological Forces. In Reich, W. (ed.) Origins of Terrorism: Psychologies, Ideologies, Theologies, States of Mind, 25-40. Woodrow Wilson Center: Washington, DC, and Johns Hopkins University Press: Baltimore and London.

Rapoport, D. C. (1990). Sacred Terror: A Contemporary Example from Islam. In Reich, W. (ed.) Origins of Terrorism: Psychologies, Ideologies, Theologies, States of Mind, 103-130. 
Woodrow Wilson Center: Washington, DC, and Johns Hopkins University Press:

Baltimore and London.

Rapoport, D. C. (2004). The Four Waves of Modern Terrorism. In Cronin, A. K. \& Ludes, J. M. (eds.) Attacking Terrorism: Elements of a Grand Strategy, 46-73. Georgetown University Press: Washington, DC.

Rashid, A. (2000). Taliban: Militant Islam, Oil and Fundamentalism in Central Asia. Yale Nota Bene: New Haven and London.

Rathbone, A. \& Rowley, C. K. (2004). Terrorism. In Rowley, C. K. \& Schneider, F. (eds.) The Encyclopedia of Public Choice, vol. II, 558-563. Kluwer Academic Publishers: Dordrecht, Boston and London.

Reich, W. (ed.) (1990). Origins of Terrorism: Psychologies, Ideologies, Theologies, States of Mind. Woodrow Wilson Center: Washington, DC, and Johns Hopkins University Press: Baltimore and London.

Rowley, C. K. (1999). Rent Seeking and Rent Extraction from the Perspective of Africa. In Kimenyi, M. S. \& Mbaku, J. M. (eds.) Institutions and Collective Choice in Developing Countries: Applications of the Theory of Public Choice, 233-254. Ashgate: Aldershot, UK and Brookfield, VT, USA.

Sandler, T. (2005a). Controlling Transnational Terrorism: Cooperation Dilemma. In Kaul, I. \& Conceição, P. (eds.) Public Finance in a Globalizing World: Innovations in Theory and Practice. Oxford University Press: New York, forthcoming.

Sandler, T. (2005b). Collective versus Unilateral Responses to Terrorism. Public Choice, forthcoming. 
Sandler, T., Tschirhart, J. T. \& Cauley, J. (1983). “A Theoretical Analysis of Transnational Terrorism". American Political Science Review 77(1): 37-54.

Shughart, W. F. II (2004). September 11, 2001. In Rowley, C. K. \& Schneider, F. (eds.) The Encyclopedia of Public Choice, vol. II, 520-524. Kluwer Academic Publishers: Dordrecht, Boston and London.

Sprinzak, E. (1990). The Psychopolitical Formation of Extreme Left Terrorism in a Democracy: The Case of the Weathermen. In Reich, W. (ed.) Origins of Terrorism: Psychologies, Ideologies, Theologies, States of Mind, 65-85. Woodrow Wilson Center: Washington, DC, and Johns Hopkins University Press: Baltimore and London.

Tullock, G. (1974). The Social Dilemma: The Economics of War and Revolution. University Publications: Blacksburg, VA.

Turk, A. T. (2004). Sociology of Terrorism. Annual Review of Sociology 30: 271-286.

Vidal, G. ([1964] 1986). Julian. Ballentine Books: New York.

Zakaria, F. (2003). The Future of Freedom: Illiberal Democracy at Home and Abroad. Norton: New York and London. 